\title{
Human-water interface in hydrological modelling: current status and future directions
}

Yoshihide Wada ${ }^{1,2}$, Marc F. P. Bierkens ${ }^{2,3}$, Ad de Roo ${ }^{2,4}$, Paul A. Dirmeyer ${ }^{5}$, James S. Famiglietti ${ }^{6}$, Naota Hanasaki ${ }^{7}$, Megan Konar $^{8}$, Junguo Liu ${ }^{1,9}$, Hannes Müller Schmied ${ }^{10,11}$, Taikan Oki ${ }^{12,13}$, Yadu Pokhrel $^{14}$, Murugesu Sivapalan ${ }^{8,15}$, Tara J. Troy ${ }^{16}$, Albert I. J. M. van Dijjk ${ }^{17}$, Tim van Emmerik ${ }^{18}$, Marjolein H. J. Van Huijgevoort ${ }^{19}$, Henny A. J. Van Lanen ${ }^{20}$, Charles J. Vörösmarty ${ }^{21,22}$, Niko Wanders ${ }^{2,23}$, and Howard Wheater ${ }^{24}$

${ }^{1}$ International Institute for Applied Systems Analysis, Schlossplatz 1, 2361 Laxenburg, Austria

${ }^{2}$ Department of Physical Geography, Utrecht University, Heidelberglaan 2, 3584 CS Utrecht, the Netherlands

${ }^{3}$ Unit Soil and Groundwater Systems, Deltares, Princetonlaan 6, 3584 CB Utrecht, the Netherlands

${ }^{4}$ Joint Research Centre, European Commission, Via Enrico Fermi 2749, 21027 Ispra, Italy

${ }^{5}$ Center for Ocean-Land-Atmosphere Studies, George Mason University, 4400 University Dr, Fairfax, VA 22030, USA

${ }^{6}$ NASA Jet Propulsion Laboratory, California Institute of Technology, 4800 Oak Grove Dr, Pasadena, CA 91109, USA

${ }^{7}$ National Institute for Environmental Studies, 16-2 Onogawa, Tsukuba, Ibaraki 305-8506, Japan

${ }^{8}$ Department of Civil and Environmental Engineering, University of Illinois at Urbana-Champaign, 205 N Mathews Ave, Urbana, IL 61801, USA

${ }^{9}$ School of Environmental Science and Engineering, South University of Science and Technology of China, No. 1008, Xueyuan Blvd, Nanshan, Shenzhen, 518055, China

${ }^{10}$ Institute of Physical Geography, Goethe University, Altenhoeferallee 1, 60438 Frankfurt am Main, Germany

${ }^{11}$ Senckenberg Biodiversity and Climate Research Centre (BiK-F), Senckenberganlage 25,

60325 Frankfurt am Main, Germany

${ }^{12}$ Institute of Industrial Science, University of Tokyo, 4-6-1 Komaba, Meguro, Tokyo 153-8505, Japan

${ }^{13}$ United Nations University, 5 Chome-53-70 Jingumae, Shibuya, Tokyo 150-8925, Japan

${ }^{14}$ Department of Civil and Environmental Engineering, Michigan State University, East Lansing, MI 48824, USA

${ }^{15}$ Department of Geography and Geographic Information Science, University of Illinois at Urbana-Champaign, Springfield Avenue, Champaign, IL 61801, USA

${ }^{16}$ Department of Civil and Environmental Engineering, Lehigh University, 1 West Packer Avenue, Bethlehem, PA 18015-3001, USA

${ }^{17}$ Fenner School of Environment \& Society, Australian National University, Linnaeus Way, Canberra,

ACT 2601, Australia

${ }^{18}$ Water Resources Section, Faculty of Civil Engineering and Geosciences, Delft University of Technology,

Stevinweg 1, 2628 CN Delft, the Netherlands

${ }^{19}$ Program in Atmospheric and Oceanic Sciences, Princeton University, 300 Forrestal Rd, Princeton, NJ 08544, USA

${ }^{20}$ Hydrology and Quantitative Water Management Group, Wageningen University, Droevendaalsesteeg 4,

6708 BP Wageningen, the Netherlands

${ }^{21}$ Environmental Sciences Initiative, CUNY Advanced Science Research Center, 85 St Nicholas Terrace, New York, NY 10031, USA

${ }^{22}$ Civil Engineering Department, The City College of New York, 160 Convent Avenue, New York, NY 10031, USA

${ }^{23}$ Department of Civil and Environmental Engineering, Princeton University, 59 Olden St, Princeton, NJ 08540, USA

${ }^{24}$ Global Institute for Water Security, University of Saskatchewan, 11 Innovation Blvd, Saskatoon, SK S7N 3H5, Canada

Correspondence to: Yoshihide Wada (wada@iiasa.ac.at) 
Received: 26 April 2017 - Discussion started: 4 May 2017

Accepted: 22 July 2017 - Published: 23 August 2017

\begin{abstract}
Over recent decades, the global population has been rapidly increasing and human activities have altered terrestrial water fluxes to an unprecedented extent. The phenomenal growth of the human footprint has significantly modified hydrological processes in various ways (e.g. irrigation, artificial dams, and water diversion) and at various scales (from a watershed to the globe). During the early 1990s, awareness of the potential for increased water scarcity led to the first detailed global water resource assessments. Shortly thereafter, in order to analyse the human perturbation on terrestrial water resources, the first generation of largescale hydrological models (LHMs) was produced. However, at this early stage few models considered the interaction between terrestrial water fluxes and human activities, including water use and reservoir regulation, and even fewer models distinguished water use from surface water and groundwater resources. Since the early 2000s, a growing number of LHMs have incorporated human impacts on the hydrological cycle, yet the representation of human activities in hydrological models remains challenging. In this paper we provide a synthesis of progress in the development and application of human impact modelling in LHMs. We highlight a number of key challenges and discuss possible improvements in order to better represent the human-water interface in hydrological models.
\end{abstract}

\section{Introduction}

The Earth's surface has undergone drastic changes due to the human-driven alteration of land use and vegetation patterns and the management of surface water and groundwater systems (Bondeau et al., 2007; Gerten et al., 2007; Rost et al., 2008). Over the last century, the global population has quadrupled and currently exceeds 7 billion, half of whom live in urban areas. The rapidly growing population and rising food demands caused a drastic 6-fold expansion of global irrigated areas during the 20th century (Siebert et al., 2015). Human needs for water are ever-increasing, dominated currently by agricultural irrigation for food production worldwide $(>70 \%)$. However, rapid urbanization and economic development are likely to be the main drivers of increasing water demands worldwide (Wada et al., 2016c). Humans extract vast amounts of water from surface water and groundwater resources (Siebert et al., 2010; Siebert and Döll, 2010; Wisser et al., 2010; Konikow, 2011), and these amounts have increased from $\sim 500$ to $\sim 4000 \mathrm{~km}^{3} \mathrm{yr}^{-1}$ over the last 100 years (Oki and Kanae, 2006; Hoekstra and Chapagain, 2007; Hanasaki et al., 2008a, b; Wada et al., 2014). Tens of thousands of artificial dams have been built in major river systems, with total storage capacities exceeding $8000 \mathrm{~km}^{3}$ worldwide (Nilsson et al., 2005; Lehner et al., 2011). These are used to boost water supply, to provide flood control, and to serve as a source of hydropower generation to supply the energy needs of industries (Liu et al., 2015, 2016). However, regional and seasonal variations of water supply and demand are large, causing water scarcity in various regions of the world (Gleick, 2000, 2003; Vörösmarty et al., 2000; Oki and Kanae, 2006; Kummu et al., 2010). In such regions, groundwater is often intensively used to supplement the excess demand, often leading to groundwater depletion (Rodell et al., 2009; Famiglietti et al., 2011; Konikow, 2011; Gleeson et al., 2012; Scanlon et al., 2012; Taylor et al., 2013). Climate change adds further pressure on the Earth's water resources and is likely to amplify human water demands due to increasing temperatures over agricultural lands (Dirmeyer et al., 2006, 2009, 2014; Wada et al., 2013a, b; Haddeland et al., 2014; Schewe et al., 2014).

Terrestrial water fluxes have been affected by humans to an unprecedented extent and the fingerprints that humans have left on the Earth's water resources are increasingly discernible in a diverse range of records that can be seen in both surface freshwater and groundwater resources. The United Nations alerts us that in water-scarce regions the shortage of water is beginning to limit economic growth and create large uncertainties for the sustainability of future water supply (World Water Assessment Programme, 2003). Given rising levels of human footprint, and the heavy dependence of the world economy and livelihoods on water, human impacts on land and water systems are pervasive (World Water Assessment Programme, 2016). Agriculture and urbanization affect the delivery and quality of water to river and groundwater systems (Siebert et al., 2010); many river flows are regulated (Lehner et al., 2011) and threaten ecological flows (Poff et al., 2010); water use, in particular for irrigation, can be a dominant factor in the hydrological cycle, including effects on land-atmosphere feedbacks and precipitation (Wada et al., 2016a) that can have substantial non-local impacts (Dirmeyer et al., 2009; Tuinenburg et al., 2012; Wei et al., 2013; Lo and Famiglietti, 2013). In an era now designated as the Anthropocene (Steffen et al., 2011; Montanari et al., 2013; Savenije et al., 2014), global hydrology must therefore be treated as a coupled human-natural system.

During the early 1990s, awareness of the potential for global water scarcity led to the first detailed global water resource assessments comparing water availability with water use based on national statistics and observed climate information (Falkenmark, 1989; Falkenmark et al., 1997). Shortly thereafter, in order to analyse the human perturbation on wa- 
ter resources, the first generation of large-scale hydrological models (LHMs) appeared (Bierkens, 2015). These models solve the local water balance consistently across large scales and calculate river discharge by accumulating gridded runoff over a river network constructed from topographic information (Vörösmarty et al., 1989). However, at this early stage few models considered the interaction between terrestrial water fluxes and human activities, including water use and reservoir regulation, and even fewer models distinguished water use from surface water and groundwater resources (Nazemi and Wheater, 2015a, b). The phenomenal growth of the human footprint has significantly modified hydrological processes in various ways (e.g. land use, artificial dams, and water diversion) and at various scales (from a watershed to the globe) (Sivapalan et al., 2012; Sivapalan, 2015). The increasing number of recent global and regional studies show that human activities can no longer be neglected in hydrological models, since otherwise the resulting assessments will be biased towards the natural conditions in many parts of the world. Since the early 2000s, a growing number of LHMs have incorporated human impacts on the hydrological cycle; however, human representations in hydrological models are still rather simplistic.

In this paper, we review the evolution of modelling human impacts on global water resources. The paper provides a synthesis of progress in the development and application of LHMs that includes an explicit treatment of human-water interactions, the lessons learned, challenges faced, and perspectives on future extensions. In this review, a number of key challenges are identified and possible improvements are discussed. This synthesis paper is an outcome of the Symposium in Honor of Eric Wood: Observations and Modeling across Scales, held 2-3 June 2016 in Princeton, New Jersey, USA. The primary objective of this contribution is to discuss the integration of human activities into process-based hydrological modelling and to provide future directions.

\section{Evolution of representing human impacts in hydrological models}

To analyse the impacts of human-induced changes on water resources consistently across large scales, a number of LHMs have been developed since the late 1990s (Sood and Smakhtin, 2015). In the early stages, the surface water balance (e.g. runoff and evaporation) was primarily simulated in LHMs and runoff was routed down the simulated river systems (Vörösmarty et al., 1989). These calculations were then compared to population and water use data to derive the degree of human water exploitation or water scarcity primarily at an annual temporal scale (e.g. Alcamo et al., 1997, 2003a, b; Arnell, 1999; Vörösmarty et al., 2000; Oki et al., 2001). LHMs typically simulate the dynamics of soil moisture due to precipitation and evapotranspiration, the generation of runoff, and the discharge through the river network on a coarse grid $(\sim 50-100 \mathrm{~km})$. Most LHMs are based on the water balance concept and track the flows of water through a number of storages, including canopy, soil, and groundwater. Most LHMs are not fully calibrated, but in some cases they are tuned with regional parameters (Widén-Nilsson et al., 2007).

Conceptual models are often chosen as they are deemed to be robust and parsimonious in their data requirements. In fact, for water budget calculations supporting water resource assessments, these more parsimonious models can be shown to yield similar annual and sub-annual estimates to more complex models, especially in the context of the lack of comprehensive and high-quality forcing data sets (Federer et al., 1996, 2003). In recent developments, however, LHMs are becoming more physically based and process oriented, with large-scale data more readily available, and there is increasing incorporation of better hydrological representations for various processes, including runoff generation, soil physics, and groundwater representation. For example, water flows and water storages are calculated for individual hydrological components such as rivers, lakes, reservoirs, and groundwater, among others (e.g. Döll et al., 2003; Hanasaki et al., 2008a, b; Rost et al., 2008; Wada et al., 2011a, b; Pokhrel et al., 2012). More sophisticated hydrological schemes to consider seasonal difference such as in runoff, snowmelt, soil moisture, and lake and dam regulation have been implemented. Water use is now often subdivided among these different water sources into specific sectors such as irrigation, livestock, manufacturing, thermal power cooling, municipalities, and the aquatic environment (Hanasaki, 2008a, b; Wada et al., 2011a, b; Flörke et al., 2013; Pastor et al., 2014). Irrigation schemes to calculate the water demand have also been improved from simply using the difference between potential and actual evapotranspiration to using a soil moisture deficit that is dynamically coupled with hydrology. Nowadays, many LHMs consider the dynamic feedback between hydrology and human water management via irrigation-soil moisture dynamics, reservoir-streamflow interaction, and water allocation-return flow (withdrawals minus consumption) dynamics (Döll et al., 2012; Wada et al., 2014; Pokhrel et al., 2015). Regional hydrological models (RHMs) consider even more complex feedback and coevolution of coupled human-water systems (Liu et al., 2014). Many human activities, such as human-induced changes in the surface and subsurface of a watershed, are not for the purpose of changing the water cycle, but they indeed alter the water cycle and water resources. These impacts are increasingly accounted for in the current generation of LHMs and RHMs.

LHMs have been developed primarily to assess water resource availability and use under human land-water management practices (Arnell, 1999; Alcamo et al., 2003a, b; Döll et al., 2009, 2012; Gosling and Arnell, 2016; van Beek et al., 2011; Wada et al., 2011a, b, 2014; Wisser et al., 2010), but they are typically water balance models that do not solve the 
land surface energy balance (Nazemi and Wheater, 2015b; Overgaard et al., 2006), even though there were some attempts to couple land surface models (LSMs) that consider surface energy balance with global river routing models (Oki and Sud, 1998) to estimate the availability of water resources globally (Oki et al., 2001; Hanasaki et al., 2008a, b). The primary focus in their development remains the accurate simulation of river discharge at relevant scales. To achieve this, most LHMs typically employ a few parameters that can be tuned to match the simulated discharge with observations (e.g. Döll et al., 2003; Wisser et al., 2010). The underlying assumption is commonly that since the models are tuned to capture the observed discharge, other fluxes such as evapotranspiration (ET) are automatically simulated with reasonable accuracy. However, it is well known that focussing on a single criterion such as discharge does not guarantee good performance for other fluxes (Hogue et al., 2006). LHMs are designed to be used in an offline mode with given climate information provided as an external input, and are not generally coupled with global climate models (GCMs).

However, some early LHMs were developed to be incorporated as LSMs into GCMs or Earth system models (ESMs) (Yates, 1997), or as stand-alone hydrological models such as VIC (Wood et al., 1992; Nijssen et al., 2001a, b) (see Table 1 for classifications). In contrast to LHMs, LSMs have been developed as the integral components of GCMs. The development of LSMs can be traced back to early work by Thornthwaite and Mather (1957) and Manabe (1969), who developed a simple "bucket model" based on the concepts of Budyko (1965). Early LSMs used simple parameterizations for solving surface energy and water balances without explicitly simulating the influence of land use change and human water management on surface hydrological processes (Deardorff, 1978; Bonan, 1995). They are used to estimate the exchange of energy, heat, and momentum between the land surface and atmosphere in GCMs, and to close budgets. Since terrestrial hydrological processes exert a profound influence on the overlying atmosphere (Shukla and Mintz, 1982; Koster et al., 2004), LSMs have advanced through intensive improvements in the representation of vegetation, soil moisture, and groundwater processes (e.g. Lawrence et al., 2011) by both the atmospheric and hydrologic research communities (Sellers et al., 1997).

As a growing body of literature highlights the need to represent human activities in GCMs, studies have begun to incorporate human factors into a number of LSMs. For example, Pokhrel et al. $(2012,2015)$ incorporated a number of human land-water management schemes, including reservoir operation (Hanasaki et al., 2006), irrigation, and groundwater pumping into the MATSIRO LSM (Takata et al., 2003), and examined the human alteration of land surface water and energy balances. A number of other studies have incorporated similar schemes in a variety of global land surface models, including the Community Land Model (CLM; Leng et al., 2014, 2015), the Organizing Carbon and Hydrology in Dy- namic Ecosystems (ORCHIDEE) model (de Rosnay et al., 2003), and the Noah LSM (Ozdogan et al., 2010). Apart from these global studies, various regional-scale studies have also developed human impact schemes to be incorporated into GCMs (e.g. Voisin et al., 2013; Ferguson and Maxwell, 2012; Condon and Maxwell, 2014).

In addition to simulating land surface hydrology, LSMs provide the lower boundary conditions for atmospheric simulations in GCMs. They typically employ sub-hourly time steps and solve the energy balance on land, which is vital to the simulation of the diurnal patterns of surface and soil temperature variations required by their parent climate models to facilitate a dynamic linkage between land and atmosphere through continuous exchange of moisture, energy, and momentum. Considering energy balances in LSMs is crucial not only to provide the boundary fluxes to the atmospheric models, but also to simulate alteration of land surface energy partitioning due to human activities such as irrigation (Ozdogan et al., 2010; Pokhrel et al., 2012), and consequently to understand its climate impact (e.g. Boucher et al., 2004; Lo and Famiglietti, 2013; Sacks et al., 2009; Sorooshian et al., 2014). Furthermore, consideration of the energy balance also makes these models suitable for coupling with agronomy-based crop models to dynamically simulate the changes in crop growth and productivity, including stagedependent heat stress change under climate change (e.g. Osborne et al., 2015).

Some large-scale dynamic vegetation models (DVMs) include land surface hydrology and human water management, such as the LPJmL model and JULES, as an integrated component of land use and vegetation dynamics including $\mathrm{CO}_{2}$ fertilization effects (Gerten et al., 2007; Clark et al., 2011; Konzmann et al., 2013). Notwithstanding such growing sophistication, most of the current generation of LHMs, LSMs, and DVMs still fall short of simulating the direct human influence on the terrestrial freshwater systems (Nazemi and Wheater, 2015a, b; Pokhrel et al., 2016), leaving the task of representing human land-water management activities within these models, and consequently in GCMs and ESMs, as one of the grand challenges for the hydrologic research community (Wood et al., 2011).

\section{Current challenges of modelling coupled human-water interactions}

\subsection{Modelling human impacts on extremes}

Hydrological extremes (i.e. drought and flood events) and water scarcity have become more severe over the last decades in multiple regions across the world (Hisdal et al., 2001; Lins et al., 1999; Stahl et al., 2010; Jongman et al., 2012; Di Baldassarre et al., 2017), which has led to substantial societal and economic impacts (Stahl et al., 2016; Wilhite et al., 2007). Many large-scale studies focus on drought and 
Table 1. Types of models used to simulate global hydrology.

\begin{tabular}{l}
\hline Large-scale hydrological models (LHMs) \\
\hline - A detailed representation of terrestrial hydrological processes at long temporal (e.g. decades) but fine spatial resolutions \\
(e.g. 10-50 km) \\
- Inclusion of human-induced change (e.g. human water use and reservoir regulation) \\
e.g. H08 (Hanasaki et al., 2008a, b), PCR-GLOBWB (Van Beek et al., 2011; Wada et al., 2014, 2016), WADMOD-M \\
(Widén-Nilsson et al., 2007), WaterGAP (Alcamo et al., 2003a, b; Döll et al., 2003), WBMplus (Vörösmarty et al., 2000; \\
Wisser et al., 2010) \\
\hline Land surface models (LSMs) \\
- A simplified treatment of the surface hydrology associated with human-induced change \\
- A focus on the interactions of the land-atmosphere for climatic simulations in global climate models (GCMs) \\
e.g. VIC (Wood et al., 1992), NOAH (Ek et al., 2003), MATSIRO (Pokhrel et al., 2012), JULES (Clark et al., 2011), DBH \\
(Tang et al., 2007) \\
Dynamic vegetation models (DVMs) \\
- A simplified treatment of the surface hydrology and human land use change \\
- A special treatment on the biosphere that enables quantitative assessment of transient changes in \\
vegetation and land surface hydrology in response to variations in climate and anthropogenic CO 2 increase \\
e.g. LPJmL (Gerten et al., 2007; Konzmann et al., 2013), JULES (Clark et al., 2011) \\
\hline
\end{tabular}

flood induced by climate extremes (e.g. Milly et al., 2005; Hirabayashi et al., 2013; Orlowsky and Seneviratne, 2013; Dankers et al., 2014; Jongman et al., 2014; Prudhomme et al., 2014; Sheffield and Wood, 2008; van Huijgevoort et al., 2014; Wanders and van Lanen, 2015; Wanders and Wada, 2015b); however, human water management is found to be an important factor affecting regional water supply and hydrological variability (Wada et al., 2013a, b; van Loon et al., 2016; Di Baldassarre et al., 2017). Recent studies explicitly model human interventions (e.g. human water use and reservoir regulation), which enables attribution of the impact of droughts, floods, and water scarcity to natural and human processes (Di Baldassarre et al., 2013a, b; Forzieri et al., 2014; Haddeland et al., 2014; van Dijk et al., 2013; van Loon and van Lanen, 2013; Veldkamp et al., 2015; Wada et al., 2013a, b; Wanders and Wada, 2015a; He et al., 2017).

With that said, commonly used drought indicators such as the Standardized Precipitation Index (SPI) and Standardized Precipitation and Evapotranspiration Index (SPEI) are not able to capture the human impacts that affect drought in streamflow and groundwater. For example, we argue that, instead of potential, actual evapotranspiration should be used, which allows better quantification of the impact of agricultural irrigation under increasing temperatures. Figure 1 demonstrates a significant difference in the duration of droughts in California based on SPEI with potential and actual evapotranspiration under natural conditions (natural) and human water management (human). Furthermore, the influence of artificial water storage such as reservoirs on hydrological extremes including drought and flood events is obvious in intensively managed agricultural regions. Without considering human water management, modelling recent se- vere droughts, such as the California drought, would yield a very different picture, which may be misleading for developing adaptation measures. In California, drought impacts were alleviated due to extra water available from reservoirs, at least in the short term. Irrigation return flow to groundwater storage also works in a similar manner (Fig. 1). However, water use dominated by groundwater pumping led to a significant lowering of groundwater levels (Fig. 1, middle right panel), emphasizing that these processes should be incorporated into state-of-the-art hydrological models. Modelling flood events without human water management would also yield a very different picture, particularly in developed countries where regional water storage and dikes are prevalent for flood mitigation (Lauri et al., 2012; Mateo et al., 2014). Without considering these regional measures, flood events could be largely overestimated in hydrological model simulations.

\subsection{Human impact indicators}

Over the last few decades numerous water resource assessment indicators have been developed alongside the improvement in human impact modelling frameworks. As overuse of water resources emerged in various regions of the world, Falkenmark (1989) pioneered the concept of the Water Crowding Index (WCI) using a threshold value to describe different degrees of water scarcity. This indicator defines per country water stress based on the per capita annual renewable freshwater resources ( $\sim$ blue water). Annual renewable freshwater resources of $1700 \mathrm{~m}^{3} \mathrm{yr}^{-1}$ per capita are taken as the threshold below which water scarcity occurs with different levels of severity, and $1000 \mathrm{~m}^{3} \mathrm{yr}^{-1}$ per capita as a general indication of a limitation to economic development (Falkenmark et al., 1997). While this is still one of the most 

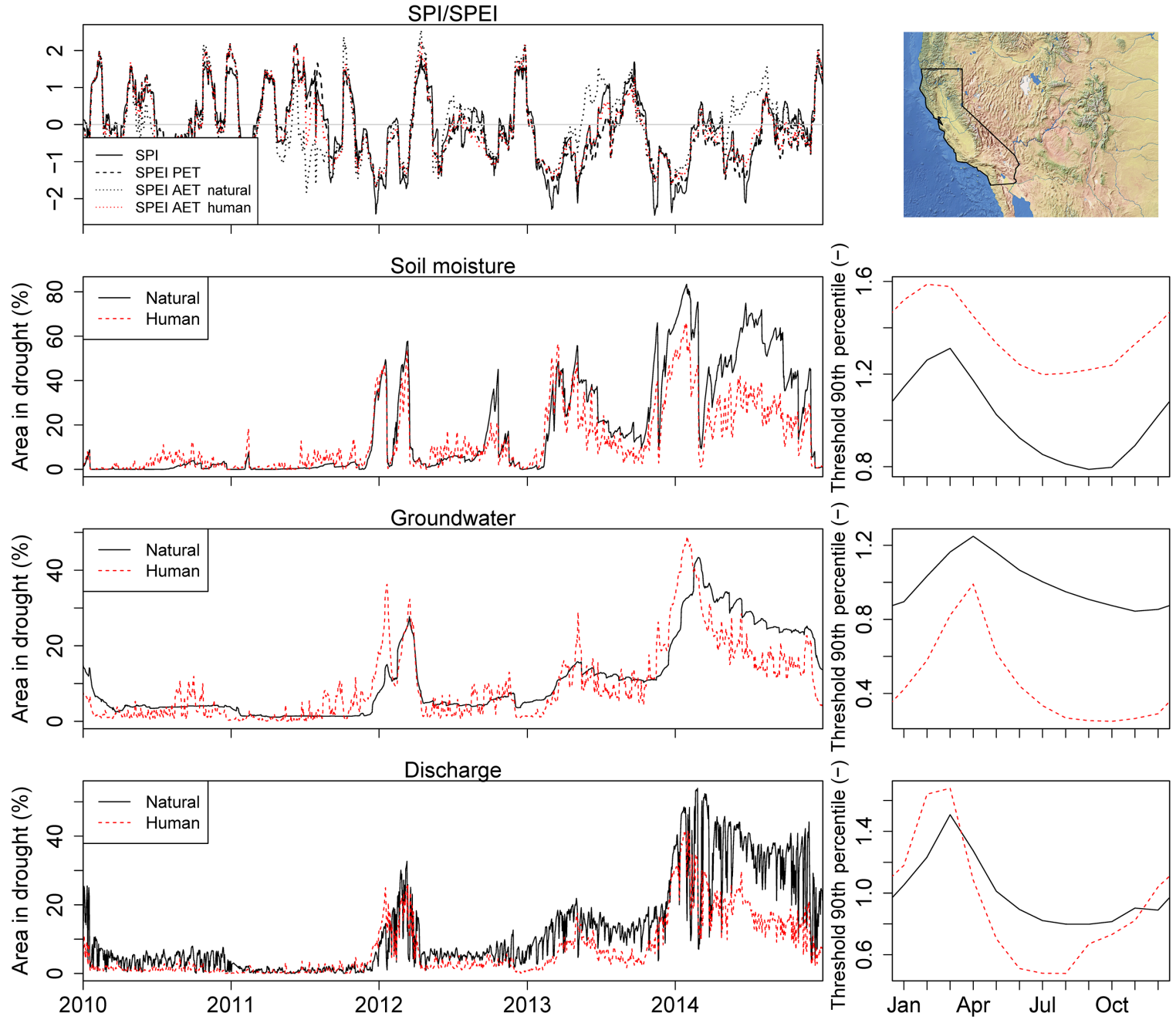

Figure 1. Area in drought (AID) in California (CA), USA, for the period 2010-2015. The PCR-GLOBWB global hydrological model (Wada et al., 2013a, b, 2014) has been used to simulate actual evapotranspiration, soil moisture, groundwater, and river discharge at a grid of $10 \mathrm{~km}$ by $10 \mathrm{~km}$ resolution. Groundwater is represented with a linear reservoir model only. We refer to Wada et al. (2014) for the detailed descriptions of model parameters and simulation. The monthly Standardized Precipitation Index (SPI), monthly Standardized Precipitation Evaporation Index with Potential Evapotranspiration (SPEI-PET), and SPEI with Actual Evapotranspiration under natural and human influenced conditions (SPEI-AET natural, SPEI-AET human) were determined at the state level. The model simulations were used to derive locally the 90th percentile variable threshold, which has been used to calculate the AID aggregated to the state level for each hydrological variable of soil moisture, groundwater, and river discharge. The 90th percentile threshold has commonly been used in drought identification (Wada et al., 2013a, b; Wanders et al., 2015, 2017) and this threshold was calculated separately for the natural situation and for the human-affected simulation shown in the right panels. All thresholds are standardized by the annual mean threshold of the natural situation.

commonly used indicators, this water scarcity metric has evolved into a more comprehensive, spatially explicit, and sector-specific index including agricultural (irrigation and livestock) and industrial water needs (Alcamo et al., 1997, 2003a, b; Arnell, 1999; Vörösmarty et al., 2000; Oki et al., 2001). Many recent studies compare total water withdrawals or consumption (agriculture, industry, and households) to water availability to express the fraction of the available water taken up by demand at the finer grid level, since countrybased estimates hide substantial within-country variation of water availability and demand (Hanasaki et al., 2008a, b; Wada et al., 2011a, b). Focusing on the African continent, Vörösmarty et al. (2005) emphasized the essential nature of the topology of river networks to differentiate between climatic and hydrologic water stress in macro-scale water resource assessments. In the current operational European water management and policy, the Water Exploitation Index (WEI) is used, reflecting both water consumption and withdrawals divided by water availability (De Roo et al., 2012). 
Water availability is local renewable freshwater with incoming streamflow from upstream parts of a river basin.

In general, a region is considered to experience water scarcity when the ratio of water withdrawal to availability is higher than 0.4 ( 0.2 in the case of water consumption), considering the sustainability of renewable water resources. In order to track the volume of water used to produce a commodity, good, or service along the various steps of production and in international trade, Hoekstra (2009) and Hoekstra and Mekonnen (2012) pioneered the water footprint concept, which classifies and quantifies the water source but does not assess the impact of human water use on natural stocks and flows, because it generally focuses on the volumes of water required without quantifying the volume of water available in the region. A few studies (Oki and Kanae, 2004; Oki et al., 2017) demonstrated how importing waterintensive commodities such as crops and meat virtually reduces water scarcity in water-crowded nations and their relationship with the economic situation of the nations. There have been recent attempts to integrate both water quantity and quality into water scarcity assessment (e.g. Liu et al, 2016; Zeng et al., 2013), and water quality including water temperature is closely linked to human interactions with water systems. In recent years, various new water resource assessment indicators have been developed (Liu et al., 2017), including the Blue Water Sustainability Indicator (BIWSI; Wada and Bierkens, 2015) that considers both renewable and non-renewable groundwater resources, and environmental flow requirements. Soil moisture $(\sim$ green water $)$ stress is still rarely assessed in the context of human water needs (Schyns et al., 2015), even though soil moisture is the major water source for global food production $(\sim 80 \%$ ) (Kummu et al., 2014).

When considering water resource assessment indicators for water scarcity and drought, classical non-transient thresholds for a baseline period (e.g. 1980-2010) are often assumed for future assessments. This may not be meaningful for considering the coming decades, when humans and nature may gradually adapt to a new hydrological state arising from either climate (Wanders et al., 2015) or other more direct drivers (Vörösmarty et al., 2010). This indicates an urgent need to develop more socially and ecologically relevant indicators that connect water science to the international society. This development should be addressed within the hydrological community.

\subsection{Modelling human impacts on groundwater resources}

The first assessments of global water resources (Falkenmark, 1989; Falkenmark et al., 1997; Alcamo et al., 2003a, b, 2007; Vörösmarty et al., 2000) were mostly focused on blue water demand and availability, where the latter was assumed to be equal to streamflow. No distinction was made between groundwater and surface water use. This distinction was un- necessary because these analyses were limited to renewable water resources and long-term averages, where streamflow also includes baseflow and it makes no difference for the budget calculations whether water is withdrawn directly from the river or from shallow groundwater pools that are in dynamic equilibrium with climate forcings. In later analyses, groundwater use was estimated implicitly (e.g. Wisser et al., 2008; Rost et al., 2008). These and subsequent assessments of groundwater use have evolved from assessments of groundwater use without hydrological feedbacks into those with feedbacks between the groundwater and surface water systems, for example, via agricultural irrigation where groundwater is supplied over irrigated areas, thereby affecting the surface water balance.

In the early developments, water demand is estimated first. Next, total water demand is attributed to available surface water and groundwater resources, leading to estimates of groundwater and surface water consumption, after subtracting return flows. As stated above, no specific feedbacks to the hydrological system are included. Instead, in order to obtain cell-specific blue water availability, for each model cell total upstream water consumption (groundwater plus surface water) is abstracted from the natural streamflow in post-process. Note that between these studies, very different assumptions were made about the allocation of water demand to surface water and groundwater. For example, in $\mathrm{H} 08$ (Hanasaki, 2008a, b, 2010), surface water is preferentially abstracted over groundwater, whereas in WBMplus (Wisser et al., 2008), water from reservoirs and groundwater is preferentially abstracted. In LPJmL (Rost et al., 2008), irrigation demand is attributed to surface water and groundwater resources using temporally invariant fractions, while in WaterGAP (Döll et al., 2012) groundwater abstractions are calculated with temporally invariant but sector- and countryspecific fractions of total water demand. In PCR-GLOBWB (van Beek et al., 2011; Wada et al., 2011a, b) local (cellspecific) groundwater abstractions are calculated by downscaling country-specific reported abstraction rates with local water demand and surface water availability.

Irrespective of the attribution approach used, these models have to deal with regions where both surface water and groundwater are insufficient to satisfy demand. The resulting water gap is either reported or is assumed to be satisfied from non-local or non-renewable water sources (Rost et al., 2008; Hanasaki et al., 2010; Vörösmarty et al., 2010), i.e. groundwater depletion or water diversions respectively. Wada et al. (2010) explicitly calculated groundwater depletion (nonrenewable groundwater abstraction) using downscaled abstraction data from the International Groundwater Resources Assessment Centre (IGRAC; https://www.un-igrac.org) and simulated recharge. The problem with this approach, however, is that it does not correct for increased capture when calculating depletion, resulting in an overestimation of depletion rates (Konikow, 2011). De Graaf et al. (2014) attempted to dynamically include groundwater abstraction in 
a global hydrological model. Here, attribution of groundwater abstraction is dynamic and based on the ratio of recharge to river discharge (groundwater to surface water availability). Abstractions are actually taken from groundwater reservoirs and affect surface water-groundwater interaction through baseflow and river infiltration. Return flows from irrigation and domestic and industrial water abstractions are included as well. Similar schemes were developed by Wada et al. (2014) and Döll et al. (2014). Although these schemes are able to mimic the interaction between groundwater pumping and hydrology, they lack the groundwater dynamics needed to represent the non-linear relationship between groundwater pumping and groundwater-surface water interaction. Building on a previously developed global hydrogeological schematization (De Graaf et al., 2015), De Graaf et al. (2017) recently calculated groundwater depletion with a two-layer transient global groundwater model coupled to the PCR-GLOBWB global hydrological model. In this study, they were able to account for increased capture leading to global depletion rates that are smaller than previously calculated by Wada et al. (2010) and are slightly larger than estimated by Konikow (2011).

Recently, groundwater use has also been incorporated into LSMs within climate models. A notable example is from a study by Wada et al. (2016a) where the contribution of groundwater depletion to sea-level change was assessed by including groundwater withdrawal and consumption in the Community Earth System Model (CESM). Pokhrel et al. (2015) incorporated a water table dynamics scheme and a pumping scheme into the LSM called the Minimal Advanced Treatment of Surface Interaction and Runoff (MATSIRO; Takata et al., 2003) to explicitly quantify the natural and human-induced groundwater storage change. These developments provide evidence that groundwater dynamics and groundwater use are slowly but surely being incorporated into the global modelling of human impacts on the terrestrial hydrological cycle. However, it should also be recognized that available global hydrogeological schematizations (e.g. Gleeson et al., 2014; De Graaf et al., 2015, 2017) are grossly over-simplified, and a joint effort is urgently needed from the hydrogeological and land surface modelling communities to improve these relatively simplistic models. Otherwise, further progress on groundwater use modelling will be seriously hampered.

\subsection{Incorporating regional water management}

It is important to note that although the influence may not be large at the global scale, urban and rural water supply infrastructure is much more diverse and regulated in many developed countries, which is not realistically accounted for in existing modelling frameworks. Seawater desalination, water diversions, and reclaimed water infrastructure are often developed to expand water supply in water-scarce regions, but these human interventions in water systems are weakly integrated in LHMs. For example, given ever-increasing water scarcity, desalination is becoming a practical and established technique to produce freshwater from saline water in coastal arid regions in the world, typically countries in the Middle East (Voutchkov, 2012). All major coastal Australian cities now also have desalination options to intermittently or permanently supplement insufficient conventional supplies. It is reported that seawater desalination contributes almost $100 \%$ of the water supply for some cities, including Makkah in Saudi Arabia (KICP, 2011). Due to the rapid development of seawater desalination plants in recent years, total capacity has been expanded from $3.52 \mathrm{~km}^{3} \mathrm{yr}^{-1}$ in 1990 to $19.16 \mathrm{~km}^{3} \mathrm{yr}^{-1}$ in 2014 (DesalData; http://www.desaldata. com).

Seawater desalination was seldom included in earlier simulation-based global water resource assessments, as it involves the production of freshwater that is unlimited by precipitation. In order to improve the accuracy of water use amounts globally, Oki et al. (2001) subtracted the equivalent volume of desalination water reported in AQUASTAT of the Food and Agriculture Organization of the United Nations (FAO) from water uses (withdrawals) in their assessments. Wada et al. (2011) spatially distributed national statistics of desalination water along the grid cells nearby the seashore. Recently, Hanasaki et al. (2016) proposed a novel method to include desalination in LHMs. They first identified the geographical distribution of areas utilizing seawater desalination (AUSD) from empirical rules utilizing global maps of aridity, GDP per capita, and distance from the coast. They then estimated the volume of desalination water production by combining the map of AUSD and a simulated water deficit (i.e. the difference between the water requirement and water availability of conventional sources). They succeeded in reproducing the spatial extent of where major seawater desalination plants exist and the volumes of past production for major countries. Their future projections report that the production of desalination water in 2041-2070 would expand to 6.7-17.3 times the current rates under various socioeconomic scenarios. Numerous challenges remain for better representation of seawater desalination. For example, recently major desalination plants have been installed in semiarid and humid climates, which is not well explained by the model of Hanasaki et al. (2016).

Other examples are long-distance and cross-basin water diversions that provide additional water supplies. Some information is available, e.g. the Periyar Project (maximum capacity: $40 \mathrm{~m}^{3} \mathrm{~s}^{-1}$ ) and Kurnool Cudappah Canal (maximum capacity: $85 \mathrm{~m}^{3} \mathrm{~s}^{-1}$ ) in India, and the IrtyshKaraganda Canal (maximum capacity: $75 \mathrm{~m}^{3} \mathrm{~s}^{-1}$ in central Asia (World Bank; http://www.worldbank.org/; UNDP; http://www.undp.org). Recently, the world's largest interbasin transfer scheme, the South-to-North Water Diversion (SNWD) project, became operational, and Beijing began to receive freshwater from the Yangtze River in China's south, which covers a distance of more than $1000 \mathrm{~km}$ (Barnett et 
al., 2015). These water diversions play a role in mitigating regional water scarcity, but also influence water balances in source and destination basins (Zhao et al., 2015). However, artificial diversion networks and the actual amount of water transferred are difficult to parameterize, and are not represented in the current generation of modelling frameworks. Extensive urban water supplies and waste water networks are also important aspects given that half the world's population currently lives in urban areas. Further efforts are needed not only for modelling, but also for comprehensive data collection of global seawater desalination, water diversion, and urban water network development.

Although desalination and inter-basin water transfer are emerging examples and likely more important in the near future, regional water management is much more complicated. Current LHMs also lack dynamic trade-offs among irrigation water supply, flooding control and hydropower production, water competitions between upstream and downstream users (Munia et al., 2016; Veldkamp et al., 2017), and deficit irrigation and rainwater harvest (Döll et al., 2014). These processes are increasingly important for regional hydrological model simulation. For example, considering regional deficit irrigation practice can reduce the water demand by $30 \%$ (Döll et al., 2014), while current LHMs predominantly use optimal irrigation practice in their model simulation. This is similar to the need to account for return flows from industry and households after water withdrawals. Water recycling and waste water treatments are becoming important mitigation measures for regional water scarcity. Modelling water recycling and waste water treatments should be combined with local water quality information, which can provide more accurate information on the absolute availability of usable water for different purposes such as drinking water, industry, and agriculture.

\subsection{Representing land use change and rapid urbanization}

Humans have transformed natural vegetation to anthropogenic land cover such as agricultural lands and pasture over $40 \%$ of the global land area (Klein Goldewijk et al., 2011; Sterling et al., 2013). Human-induced land use change has profound impacts on global and regional hydrological cycles by changing the rate of evapotranspiration, runoff, and groundwater recharge, which in turn affects regional precipitation patterns and inflows to oceans (Gordon et al., 2005; Halder et al., 2016; Puma and Cook, 2010; Renner et al., 2014). Human transformation of global land cover (excluding irrigated agriculture) generally decreases evapotranspiration and increases runoff (Gordon et al., 2005). Many LHMs include the impacts of land use change; however, the land use representation in the model tends to be statically prescribed as an input parameter, while dynamic change in historical land use is a lesser focus. Compared to LHMs or LSMs,
DVMs have better representation of land cover change, while land surface hydrology is treated rather simply.

Among different land use changes, urbanization is of specific interest in recent impact studies, e.g. with the focus on flood risks, hazards, and vulnerability (Güneralp et al., 2015; Muis et al., 2015; Sampson et al., 2015; Tanoue et al., 2016; Winsemius et al., 2013). At present, more than half of the world's population lives in urban areas and rapid urbanization is taking place in many developed and developing regions of the world (Klein Goldewijk et al., 2011). Nevertheless, urban areas and their impact on the hydrological cycle (e.g. Jacobson, 2011) are not well represented in LHMs, mostly due to their small proportion of the global land area (Wood et al., 2011). Although the impact of urban areas on the water cycle may be local, the distribution of such areas is of high importance, e.g. for heat island and urban flood modelling (Yang et al., 2011). Among LHMs, WaterGAP uses a static input map with the percentage of impervious areas at a grid and assumes that $50 \%$ of precipitation over those areas directly reaches the surface water bodies (Müller Schmied et al., 2014). The LISFLOOD water resource model (De Roo et al., 2000) uses sub-grid fractions of urban, forest, open water, and several other land usages within the $0.1^{\circ}$ (global) or $5 \mathrm{~km}$ by $5 \mathrm{~km}$ grid scale (for Europe) to represent the effects of land use. Several (soil) hydrological processes are consequently simulated separately (De Roo et al., 2012). Figure 2 shows the percentage of urban area at a $0.5^{\circ}$ grid based on MODIS urban land cover classification for the year 2003. However, scale issues arise for urban land cover due to the fact that the effect of limited urban areas on the water cycle can be diminished at a large grid cell (Warburton et al., 2012) and coherent scaling relationships are missing (Reyes et al., 2016). However, satellite mapping of urban or impervious areas has improved recently (Lopez and Maxwell, 2016; Wohlfart et al., 2016; Yang et al., 2003) using the Moderate Resolution Imaging Spectroradiometer (MODIS) satellite images (Schneider et al., 2009).

A recent study shows the challenges of including smallscale urban hydrological modelling (Reyes et al., 2016). However, representing urban areas as sub-grid variability and upscaling the effect of urban areas to the larger hydrological cycle may be possible (Krebs et al., 2014). For example, model simulation with and without urban areas and associated hydrological balance can be compared in urbanized catchments to see the impacts and their validation with available observations (e.g. runoff and evapotranspiration). Here, the percentage of runoff that is generated over the impervious areas may be validated and tuned to generalize the concept.

In order to better represent urban impacts on the regional hydrological cycle, more accurate assessments of urban water withdrawals and consumption are vital (Flörke et al., 2013; Wada et al., 2016b, c). Finer spatial-scale population and socio-economic data are required worldwide; however, these data are typically provided at a country scale or a $0.5^{\circ}$ grid. This leads urban water demands and supply to be geo- 


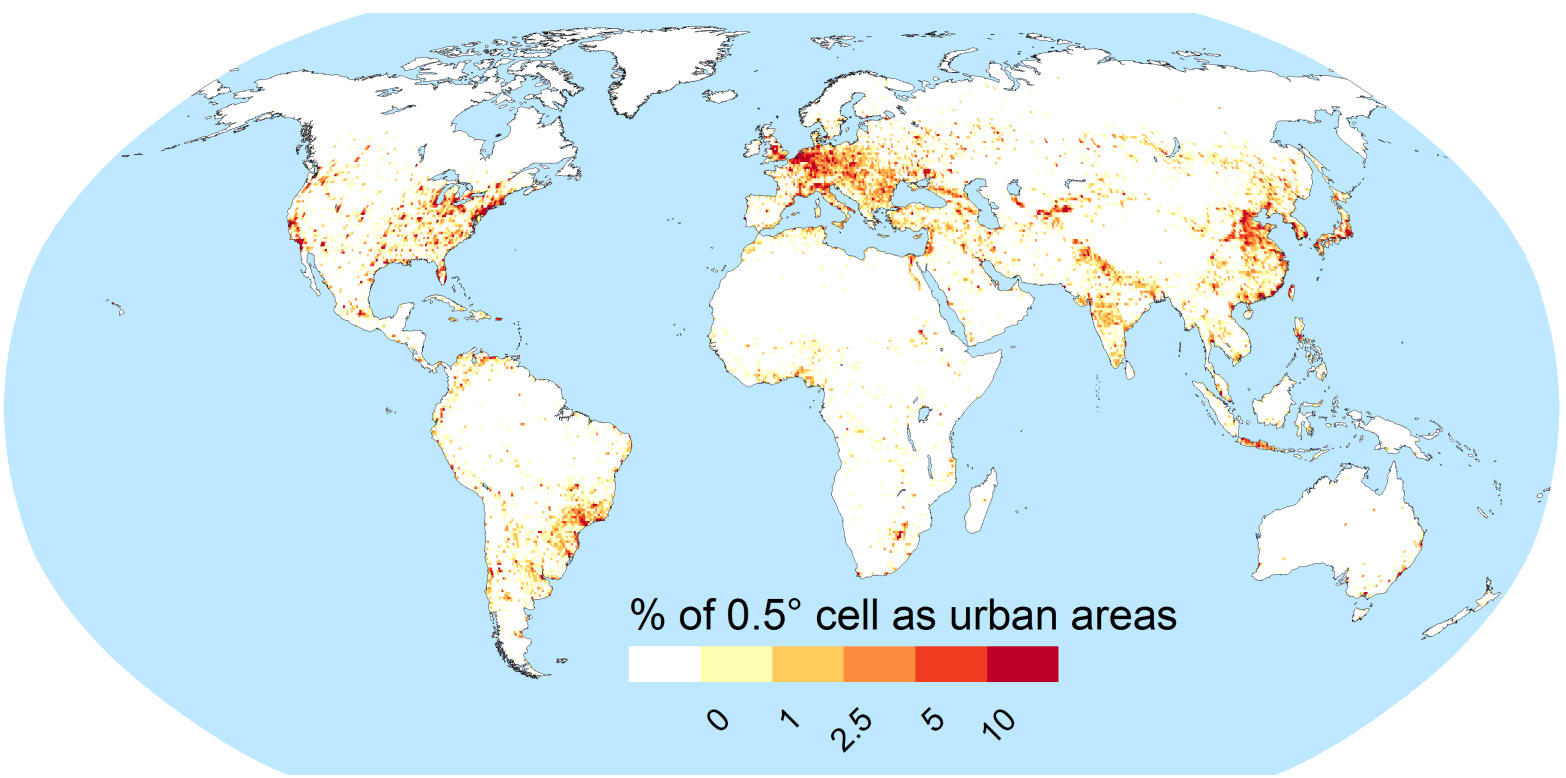

Figure 2. MODIS urban land cover as percentages of a $0.5^{\circ}$ grid cell for the year 2003 (IGBP classification system, class 13). The calculation was done with a resampled land cover type of $0.025^{\circ}$ tiles $(2.7 \times 2.7 \mathrm{~km}$ at the Equator $)$ for technical reasons. Hence, urban land cover has to be dominant in a sub-grid in order to be taken into account for a $0.5^{\circ}$ grid urban percentage. The assessment of the whole time series of MODIS land cover data (yearly data 2003-2013) shows a very robust classification, implying that during that decade and using the resampled information, not much change is detected (the maximum difference is $1.2 \%$ among the years).

graphically mismatched in current large-scale water resource assessments, and associated water scarcity and groundwater depletion are not well represented (e.g. Döll et al., 2014; Wada et al., 2014). McDonald et al. (2014) included the source of urban water supply, which led to improved water scarcity assessments. Considering a rapidly increasing urban population, the model representation of urban hydrology and water management needs to be urgently considered.

\section{A look forward}

\subsection{Modelling human activities at multiple spatial scales}

Local human behaviour is an important part of the hydrological system as humans are not just external drivers or boundary conditions in hydrological systems (Sivapalan, 2012, 2015; Montanari et al., 2013; Troy et al., 2015a, b; van Loon et al., 2016). The field of socio-hydrology is focused on understanding the processes that link humans and water in a coupled hydrological-social system (Sivapalan et al., 2012, 2014). Socio-hydrology has emerged relatively recently as a discipline that addresses the intersection between human and natural systems (e.g. Sivapalan et al., 2012; Gober and Wheater, 2015). The basic concepts of socio-hydrology align well with the mainstream of coupled human and natural large-scale modelling efforts that have rapidly developed since the late 1990s, as discussed earlier in this paper (e.g.
Alcamo et al., 1997; Vörösmarty et al., 2000; Oki et al., 2001; Döll et al., 2003). However, a main difference of sociohydrology from the large-scale human impact modelling is to link bi-directional feedbacks between hydrological processes and local human behaviour, similar to agent-based modelling (ABM). Thus, socio-hydrology can be seen as a new development in human impact modelling but, so far, is primarily focused on a local to regional scale, and still requires more detailed parameterizations of human behaviour and processoriented modelling frameworks.

Socio-hydrological studies can be divided into (1) historical studies, (2) comparative studies, and (3) processbased studies. For example, as a historical study, Pande and Ertsen (2014) investigated complex cooperative agreements from ancient societies, and found that it was in fact water scarcity that triggered cooperation. For a more recent example, Kandasamy et al. (2014) revealed a "pendulum" swing in the Murrumbidgee River basin, where population first increased, driven by agricultural development, and later decreased, driven by environmental restoration being more favoured over agriculture. In recent years several socio-hydrological models have been developed (Blair and Buytaert, 2016; Troy et al., 2015a). Di Baldassarre et al. (2013a, b) and Viglione et al. (2014) developed a conceptual "toy model" that explores the dynamics of a floodplain as a coupled human-water system. They demonstrated the relationships between the hydrological and social cycles, as human settlements in floodplains are threatened by 
flooding. Based on this it was revealed how societal memory of historical floods determines the (re)settling rate, and whether a society is economically growing or recessing. Several large river basins have been studied extensively, such as the Murrumbigee River basin (van Emmerik et al., 2014), the Kissimmee River basin (Chen et al., 2016), and the Tarim basin (Liu et al., 2014), yielding new insights into the governing hydro-social processes and relations that operate in these coupled systems. To go beyond single case studies, Elshafei et al. (2014) developed a generic framework for socio-hydrological modelling of agricultural catchments. Although the application to two Australian catchments was insightful, it remains challenging to link human and hydrological processes across multiple spatial scales over different geographies. The launch of socio-hydrology offers a new paradigm that enables us to evaluate the co-evolution of human activities and hydrology, driven by two-way feedbacks between humans and water systems over long time horizons, which was not fully addressed in the large-scale human impact modelling efforts.

Besides new opportunities and new insights, sociohydrology can also be seen as a wicked problem (Levy et al., 2016). Human reactions to hydrological extremes can be contrasting (Loucks, 2015), and there are no widely accepted laws yet for human behaviour in coupled systems (Sivapalan and Blöschl, 2015; Levy et al., 2016). This leads to model developers deriving relations and identifying governing processes individually for each case study. Many sociohydrological models consist of coupled differential equations that capture the dynamics of the studied system. However, it is unclear whether this is because of over-parameterization or mathematical correctness (Troy et al., 2015a; Mount et al., 2016). Either way, it is time for socio-hydrology to move beyond individual case studies and find generalized but locally relevant descriptions of changes in the (large-scale) humanwater system (McMillan et al., 2016). Importantly, a recent study has presented a generalized socio-hydrology model of water resources and trade (Dang et al., 2016), which also highlights the opposite challenge in socio-hydrology model development, e.g. no explicit spatial representation in many economics models.

Ways forward for socio-hydrology include testing model structures and frameworks in multiple case studies, or upscaling their model boundaries and increasing the modelled system scale, and using new data, information sources, and modelling environments. Here lies the confluence where socio-hydrology models and global (hyper-)resolution models (Wood et al., 2011) might benefit from each other. Many LHMs nowadays incorporate human water management, but as discussed earlier, large uncertainties remain in model simulations (Döll et al., 2016). However, it should be noted that many recent studies report that including human influences in regional hydrology improves model performance in simulating river discharge or groundwater storage (Wada et al., 2015; Wanders and Wada, 2015a, b). For example, Yin et al. (2017) applied an ensemble of global model outputs with regional water management practices in the Yellow River basin, which yielded better surface water availability among the sub-river basins. This type of offline coupling of global models with regional water management information will facilitate the use of global models for regional application. In addition, further improvement in modelling human impact processes is crucial for realistic hydrological predictions.

Implementing local socio-hydrology models in large-scale hydrological models should be done with care, as it is important to be mindful of the temporal and spatial scales used. Human decision making is generally modelled on a yearly basis or lumped together as collective social structures. Integrated assessment models (IAMs) such as the Global Change Assessment Model (GCAM) which combine economy, energy, agriculture, climate, and water resource assessment with long-term policy development can also provide a good opportunity for studying the intersection between human and natural systems in a large-scale system (Hejazi et al., 2013a, b, 2014). Socio-hydrological modelling should be done either on the smallest scale (Pande and Ertsen, 2014) or on the largest societal and environmental scale (society and climate) (Ertsen et al., 2014). This is also crucial for later calibration and validation, as these should keep pace with the increase in spatial model resolution to resolve the relevant processes (Melsen et al., 2016). There should be a coordinated way forward for socio-hydrology and global (hyper-)resolution modelling efforts. Incorporating human activities globally as an endogenous factor will provide material for comparative studies for the socio-hydrological communities, increased model realism in LHMs, and better predictions of the co-evolution of the coupled human-water system.

\subsection{Global models for regional use}

Global models are specially designed for application to the global domain. They use boundary conditions and parameters that can be derived only from globally available data sets and use a limited number of robust parameters that can be used without formal parameter calibration. However, global models have recently been used for many regional applications, which requires careful attention to how to set up global models for specific regional case studies. A straightforward approach is to run a global model for the global domain with a standard setting and focus on analysis of the results for some specific regions. Biemans et al. (2013) used the LPJmL model (Biemans et al., 2011; Rost et al., 2008) to study future irrigation and food production in the Indian subcontinent under climate change. In their simulations, the basic settings were identical to the global simulation (e.g. the spatial resolution was $0.5^{\circ}$ by $0.5^{\circ}$ or 50 by $50 \mathrm{~km}$ at the Equator). Earlier work by Vörösmarty et al. (1998) highlighted problems of re-scaling global water balance models to sub-global domains, using the data-rich United States as an example, re- 
vealing the numerical "penalties" of data incongruities and model formulations that would eventually be encountered in fully global-scale analysis.

An advanced approach is to increase the spatial resolution of global models to better represent the regional details. Wada et al. (2016b) applied the PCR-GLOBWB model at a spatial resolution of $0.1^{\circ}$ by $0.1^{\circ}$. Some models allow users to set the spatial domain and resolution freely. Mateo et al. (2014) applied the H08 model (Hanasaki et al., 2008a, b) to the Chao Phraya River in Thailand at a spatial resolution of $5^{\prime}$ by $5^{\prime}$. Unlike the above-mentioned global studies, they tuned several important hydrological parameters at major river gauging stations by collecting historical meteorological and hydrological data. They succeeded in reproducing the historical long-term river discharge of the basin, including the operation of two major reservoirs and the areal expansion of inundation for a large flood event in 2011. Hanasaki et al. (2014) extended their model to quasi-real-time simulation for possible application for flood monitoring in the Chao Phraya River. Masood et al. (2015) applied the model to the Ganges, Brahmaputra, and Megna rivers in South Asia. The Australian Water Resources Assessment (AWRA) system (van Dijk and Renzullo, 2011) couples daily time-step catchment and groundwater balance models at $0.05^{\circ}$ resolution with a (regulated) river and reservoir model. It is used operationally by the Bureau of Meteorology to produce regular water resource assessments and water accounts (http://www.bom.gov.au/water/). Gosling et al. (2017) compared the simulated results of river runoff for eight large river basins in the world by using an ensemble of global to continental LHMs and an ensemble of regional catchment-scale hydrological models. The two types of model at different spatial scales showed similar trends for the effects of global warming, indicating the possible application of LHMs for regional use. Either way, i.e. increasing spatial resolution of global models or applying global models for a specific region or catchment with fine resolution, potentially removes the barriers between regional and global models (Hattermann et al., 2017). However, ongoing efforts towards better representation of regional details are required, which would eventually improve both global models and fine-scale simulation.

\subsection{Need for model intercomparison}

Modelling human behaviour is highly uncertain, but the use of a single hydrological model is still valuable to test a hypothesis, provided it is succeeded by a multi-model analysis to examine the full range of possible human impacts and model uncertainties (Tallaksen and Stahl, 2014; van Huijgevoort et al., 2013, 2014). A number of model intercomparison projects on large-scale models have been performed (e.g. GSWP1, GSWP2, WaterMIP, and ISIMIP), and the strengths, weaknesses, and characteristics of individual models have been compared. The focus has been on the historical energy and water balances over land (Dirmeyer et al., 2006; Douglas et al., 2006), water balance and river discharge of the past (Oki et al., 1999; Haddeland et al., 2011) and future (Hagemann et al., 2013; Schewe et al., 2014), as well as water use (Wada et al., 2013a, b, 2016c).

One of the model components that inter-comparisons have not addressed is the operation of dams. About 50000 dams have been constructed globally (Lehner et al., 2011) and some models explicitly simulate the operation of major dams in the world (Hanasaki et al., 2006; Biemans et al., 2011; Wada et al., 2011). Masaki et al. (2017) were the first to compare the simulation results of reservoir operations of five large-scale hydrological models. They used the retrospective multi-model simulation data set of the ISIMIP 2a project (https://www.isimip.org/) and focused on the reservoirs of the Missouri and Colorado rivers in the USA. Although all of the models adopted similar algorithms of reservoir operation and used harmonized meteorological and geographical data, there were considerable differences between them. They analysed the results of only two rivers in the USA; a more systematic inter-comparison is needed that covers other regions of the world. It should also be noted that for validation of reservoir operations, data including inflow, outflow, and actual reservoir volume are not readily available worldwide, often due to political sensitivity.

\subsection{Observing and sharing information on human water management}

As mentioned several times throughout this paper and elsewhere (Lawford et al., 2013; Harding et al., 2014; Fekete et al., 2015), there is a serious lack of comprehensive data required to adequately constrain and evaluate hydrological models over continental to global scales. The data gaps limit our ability to fully assess model accuracy for the past, and hence to develop reliable models to predict the future. While relatively more reliable data for some hydrologic variables, such as precipitation, air temperature, and river discharge, are available for many regions, data on groundwater and human water use are particularly lacking. Regional groundwater data sets are now becoming increasingly available (e.g. Scanlon et al., 2006; Fan et al., 2013), but significant challenges still remain in collecting and synthesizing data with global coverage because even the available data for most regions are not easily accessible (e.g. Hannah et al., 2011). Vast amounts of soil and aquifer analyses, including hydrogeological frameworks and measurements, have been made, but the data remain dispersed and unstructured in the scientific literature, government archives, and online repositories. It is therefore essential to make community-driven efforts to compile these scattered data sets into a comprehensive hydrogeological information system easily accessible to the modelling community (Fan et al., 2015). Some of the available global data sets include FAO AQUASTAT for water use databases, IGRAC groundwater data, the Global Runoff Data Centre (GRDC) for river flow, and the International Commission on 
Large Dams (ICOLD) reservoir data, but data often require substantial re-vetting and interpretation to be used for modelling studies (Lehner et al., 2011), and commonly lack information on operating rules. The hydrologic modelling community has benefitted considerably from coordinated data collection and distribution efforts in the past, but it is time to revise these data sets to meet the growing need for more comprehensive, spatially explicit, time-varying data on human interactions with the hydrological cycle (Gleick et al., 2013).

Recently, use of remote sensing has provided an unprecedented opportunity to fill the spatial and temporal gaps in ground-based observations for large-scale modelling. For example, the data obtained from the Advanced Very High Resolution Radiometer (AVHRR), the Landsat mission, and the Moderate-Resolution Imaging Spectroradiometer (MODIS) have provided a unique opportunity to derive human-transformed land use information. For example, MODIS data have been utilized to derive global ET at very high spatial resolutions (Mu et al., 2011; Tang et al., 2009; Zhang et al., 2010), which can be used for the evaluation of global and regional irrigation impacts. The Shuttle Radar Topography Mission (SRTM) provides high-resolution topography data useful for global and regional water transport and groundwater modelling. Satellite radar altimetry and laser altimetry have provided measurements that can be used to derive water surface elevation of lakes and man-made reservoirs (Gao, 2015). The Tropical Rainfall Monitoring Mission (TRMM) delivers high-resolution rainfall data for mid- and low-latitude regions for climate forcing.

In recent decades, satellite observations, such as by the Gravity Recovery and Climate Experiment (GRACE) satellite mission (Tapley et al., 2004), have further advanced our ability to better monitor the continually evolving surface and groundwater systems especially in relation to the changing climate and growing human interventions (Famiglietti et al., 2015; Lettenmaier and Famiglietti, 2006). GRACE data have been used to infer the changes in terrestrial water storage over large regions and have been widely used to study human-induced changes in surface and groundwater storages (Rodell et al., 2009; Strassberg et al., 2009; Scanlon et al., 2012; Longuevergne et al., 2010; Famiglietti et al., 2011; van Dijk et al., 2014). The Global Precipitation Measurement (GPM), Soil Moisture Active Passive (SMAP), and Surface Water and Ocean Topography (SWOT) mission are expected to provide better information on how human activities affect terrestrial water fluxes.

Satellite observations have enabled us to better constrain and evaluate human activities in hydrological models (Famiglietti et al., 2015). This is of particular interest for less-gauged basins where conventional data are scarce. Several studies have demonstrated the use of combinations of available remote sensing products to force, calibrate, and/or validate hydrological models to increase understanding of the hydrological behaviour and the influence of human activi- ties (e.g. Winsemius et al., 2009). However, there are inherent uncertainties and limitations in satellite-derived products (Fekete et al., 2015). Satellite data usually provide global coverage filling the spatial gap in ground-based observations, but their temporal coverage may be limited. In addition, satellite-derived products can contain significant uncertainties because certain algorithms have to be used to derive the desired geophysical product since satellites typically measure the surface characteristics of the Earth rather than the geophysical variables themselves. Therefore, it is important to maintain ground-based observational networks in parallel with the advancements in remote sensing technology because the satellite-derived products need to be verified with independent observations (Famiglietti et al., 2015). In fact, the TRMM Multi-satellite Precipitation Analysis (TMPA) combines products from multiple satellite and ground observations from the Global Precipitation Climatology Centre (GPCC) (Huffman et al., 2007). Recent studies also evaluated the consistency between the pure satellite-based measurements (TRMM) and TMPA at regional scale (e.g. Villarini, 2010) and global scales (e.g. Zhou et al., 2014).

\subsection{Linking human impact modelling to policy development}

Given that human impacts on land and water systems are pervasive, a basic requirement for hydrological science to support local, regional, and global policies is to deliver "realworld" ESMs that incorporate the more important physical controls associated with human influences, e.g. land use, dams, and irrigation (Wheater and Gober, 2015). These are needed to support decision making at multiple scales, from local-scale impacts of agricultural land management and urbanization to global-scale analysis and prediction of Earth system change, including land-atmosphere feedbacks and land-ocean freshwater delivery. Human impacts are most readily understood and represented in local-scale models, where for example process-based models have access to local information on physical infrastructure, water demands, and allocation rules. However, important challenges remain at that scale, for example representation of impacts of agriculture on runoff and water quality (e.g. nutrition, salinity, and pesticides). At larger spatial domains, including large river basins and transboundary waters, representing even these basic effects of human activities becomes challenging (De Lange et al., 2014). For example, data on physical infrastructure are limited at these scales, operational rules are often unknown, and while information on water allocations may or may not be available, actual water use generally has to be estimated. Nazemi and Wheater $(2015 a, b)$ discuss the needs for new data, satellite observational tools, models, and comparative analyses, as well as enhanced global coordination, to address these issues. It is evident, however, that the representation of human impacts includes not only data on physical infrastructure, but also societal and cultural behaviour. 
To take a simple example, operational policies for water infrastructure may not be known to downstream users, yet may have a large impact on downstream flows, and water use (as opposed to allocations) will depend on governance structures and user decisions. It therefore follows that there is a set of more complex needs for management and policy, which includes societal behaviour. It is perhaps obvious that societal behaviour is an integral aspect of both policy and operational water management, but it is also important to recognize that, just as geomorphological processes influence the long-term evolution of the water environment, so do human actions. As described earlier in the case of the Murrumbidgee River basin, co-evolution of human-water systems led to a government action that bought back water rights for the environment, invested in improved water use efficiency, and increased environmental protection, so that environmental health is returning and water use is retreating downstream. The authors ask - could this have been predicted - and state that "prediction of water cycle dynamics over long timescales is not feasible without including the interactions and feedbacks with human systems" (Wheater and Gober, 2015). So, for example, as society attempts to manage uncertain risks from environmental change, recognizing the non-stationarity of climate (Milly et al., 2008), it is equally important to address the non-stationarities associated with land and water management.

As we expand to larger spatial scales, many water-scarce regions start to rely on external water transfers, including water diverted from other basins and virtual water from other regions via international trade, to alleviate local water problems (Hejazi et al., 2014; Zhao et al., 2015). Globalization, water diversion, and virtual water also have far-reaching effects on regional water use and hydrological cycles (Pande and Sivapalan, 2016). Hydrological models do not thus far have the capacity to capture the role of these tele-coupling water management systems. Coupled hydro-economic models are therefore needed to understand the effects of human behaviour in one place on the water systems in another place.

As a final point in this discussion of the importance of human impact modelling for policy, we suggest that a further dimension of coupled human and water systems (Gober and Wheater, 2015) concerns communication and stakeholder engagements. In commenting on the flood-plain example, Gober and Wheater (2015) note that "The concept of social memory does not, however, adequately capture the social processes whereby public perceptions are translated into policy action, including the pivotal role played by the media in intensifying or attenuating perceived flood risk, the success of policy entrepreneurs in keeping flood hazard on the public agenda during short windows of opportunity for policy action, and different societal approaches to managing flood risk that derive from cultural values and economic interests." This limited example illustrates that there is a rich agenda to better understand human-water interactions as a guide to policy development and implementation. More gen- erally, Gober and Wheater (2015) note the general failure to link science with policy and associated needs for two-way iterative engagement between producers and users of scientific information to build trust and better understand the needs of policy makers and other users, and what scientists can provide to assist policy making. This could include public engagement; for example, public attitudes can be an important factor in political decisions relating to societal values associated with water management, such as the trade-offs between human water use and environmental flows.

\section{Conclusions}

This paper builds upon contributions from previous modelling efforts aimed at incorporating human activities in hydrology and in large-scale water resource assessments, and has tried to highlight the need for further improvements, including a number of key unsolved questions. To further advance the current generation of hydrological models, we have explored the possibility of including different modelling aspects of coupling human-water systems to hydrological models. The outstanding issues and shortcomings of previous large-scale water resource assessments can be grouped into five major themes: (1) issues related to current human impact modelling and associated indicators, (2) issues related to the limitations in representing regional water management, (3) issues related to the need to model the co-evolution of human-water systems, including land use and climate interaction, (4) issues related to the need for a nested approach integrating human behaviour (bottom-up) into large-scale modelling (top-down), and (5) issues related to the lack of human water management information. These five themes make up the current major challenges for the human-water interface in hydrological modelling that need substantial progress in the coming years. Despite the various limitations identified, current modelling frameworks have advanced significantly beyond earlier modelling work by accounting more realistically for human activities and the associated impacts on the terrestrial water system. Further progress in the modelling of coupled human-water systems at a range of spatial scales will be important milestones not only for the hydrological science community, but also for the climate and Earth system science communities. The future of human impact modelling as outlined in this paper offers a valuable opportunity for the hydrologic research community to become a more truly interdisciplinary and influential Earth science than ever before.

Data availability. The data and model simulation used to produce Fig. 1 are available at https://doi.org/hdl:10411/GP5PKK (Wanders et al., 2017).

The global hydrological model PCR-GLOBWB used to produce the data in Fig. 1 is an open-source hydrological model that can be 
obtained from Utrecht University (http://www.globalhydrology.nl/ models/pcr-globwb-2-0/, Hydrology Group, 2017).

Competing interests. The authors declare that they have no conflict of interest.

Special issue statement. This article is part of the special issue "Observations and modeling of land surface water and energy exchanges across scales: special issue in Honor of Eric F. Wood". It is a result of the Symposium in Honor of Eric F. Wood: Observations and Modeling across Scales, Princeton, New Jersey, USA, 2-3 June 2016.

Acknowledgements. This study is an outcome of the Symposium in Honor of Eric Wood: Observations and Modeling across Scales held at Princeton University during 2-3 June 2016. The authors are grateful for productive discussion during the symposium, which substantially contributed to this work. We thank Eric Wood for his lifelong devotion and guidance towards global efforts to improve the understanding and practical relevance of hydrological science. We wish to thank Qiuhong Tang, Tian Zhou, and Pat Yeh for their thoughtful comments and constructive suggestions, which substantially improved the quality of the manuscript. Junguo Liu received funding from the National Natural Science Foundation of China (41625001).

Edited by: Dennis Lettenmaier

Reviewed by: Qiuhong Tang, Pat Yeh, and Tian Zhou

\section{References}

Alcamo, J., Döll, P., Kaspar, F., and Siebert, S.: Global change and global scenarios of water use and availability: an application of WaterGAP1.0, Rep. A9701, Cent. for Environ. Syst. Res., Univ. of Kassel, Kassel, Germany, 1997.

Alcamo, J., Döll, P., Henrichs, T., Kaspar, F., Lehner, B., Rösch, T., and Siebert, S.: Development and testing of the WaterGAP 2 global model of water use and availability, Hydrol. Sci. J., 48, 317-337, https://doi.org/10.1623/hysj.48.3.317.45290, 2003a.

Alcamo, J., Döll, P., Henrichs, T., Kaspar, F., Lehner, B., Rösch, T., and Siebert, S.: Global estimation of water withdrawals and availability under current and "business as usual" conditions, Hydrol. Sci. J., 48, 339-348, https://doi.org/10.1623/hysj.48.3.339.45278, 2003b.

Alcamo, J., Flörke, M., and Märker, M.: Future long-term changes in global water resources driven by socio-economic and climatic changes, Hydrol. Sci. J., 52, 247-275, https://doi.org/10.1623/hysj.52.2.247, 2007.

Arnell, N. W.: Climate change and global water resources, Global Environ. Chang., 9, 31-49, https://doi.org/10.1016/S09593780(99)00017-5, 1999.

Barnett, J., Rogers, S., Webber, M., Finlayson, B., and Wang, M.: Sustainability: transfer project cannot meet China's water needs, Nature, 527, 295-297, https://doi.org/10.1038/527295a, 2015.
Biemans, H., Haddeland, I., Kabat, P., Ludwig, F., Hutjes, R. W. A., Heinke, J., von Bloh, W., and Gerten, D.: Impact of reservoirs on river discharge and irrigation water supply during the 20th century, Water Resour. Res., 47, W03509, https://doi.org/10.1029/2009wr008929, 2011.

Biemans, H., Speelman, L. H., Ludwig, F., Moors, E. J., Wiltshire, A. J., Kumar, P., Gerten, D., and Kabat, P.: Future water resources for food production in five South Asian river basins and potential for adaptation - A modeling study, Sci. Total Environ., 468-469, Supplement, S117-S131, https://doi.org/10.1016/j.scitotenv.2013.05.092, 2013.

Bierkens, M. F. P.: Global hydrology 2015: State, trends, and directions, Water Resour. Res., 51, 4923-4947, https://doi.org/10.1002/2015WR017173, 2015.

Blair, P. and Buytaert, W.: Socio-hydrological modelling: a review asking “why, what and how?", Hydrol. Earth Syst. Sci., 20, 443 478, https://doi.org/10.5194/hess-20-443-2016, 2016.

Bonan, G. B.: Land-atmosphere $\mathrm{CO}_{2}$ exchange simulated by a land surface process model coupled to an atmospheric general circulation model, J. Geophys. Res. Atmos., 100, 2817-2831, https://doi.org/10.1029/94JD02961, 1995.

Bondeau, A., Smith, P. C., Zaehle, S., Schaphoff, S., Lucht, W., Cramer, W., Gerten, D., Reichstein, M., and Smith, B.: Modeling the role of agriculture for the 20th century, Global Change Biol., 13, 679-706, https://doi.org/10.1111/j.1365-2486.2006.01305.x, 2007.

Boucher, O., Myhre, G., and Myhre, A.: Direct human influence of irrigation on atmospheric water vapour and climate, Clim. Dynam., 22, 597-603, https://doi.org/10.1007/s00382-004-0402-4, 2004.

Budyko, M.: The Heat Balance of the Earth's Surface, Soviet Geography Review and Translation, 6, 303-310, 1965.

Chen, X., Wang, D., Tian, F., and Sivapalan, M.: From channelization to restoration: Sociohydrologic modeling with changing community preferences in the Kissimmee River Basin, Florida, Water Resour. Res., 52, 1227-1244, https://doi.org/10.1002/2015WR018194, 2016.

Clark, D. B., Mercado, L. M., Sitch, S., Jones, C. D., Gedney, N., Best, M. J., Pryor, M., Rooney, G. G., Essery, R. L. H., Blyth, E., Boucher, O., Harding, R. J., Huntingford, C., and Cox, P. M.: The Joint UK Land Environment Simulator (JULES), model description - Part 2: Carbon fluxes and vegetation dynamics, Geosci. Model Dev., 4, 701-722, https://doi.org/10.5194/gmd-4701-2011, 2011.

Condon, L. E. and Maxwell, R. M.: Feedbacks between managed irrigation and water availability: Diagnosing temporal and spatial patterns using an integrated hydrologic model, Water Resour. Res., 50, 2600-2616, https://doi.org/10.1002/2013WR014868, 2014.

Dang, Q., Konar, M., Reimer, J. J., Di Baldassarre, G., Zeng, R., and Lin, X.: A theoretical model of water and trade, Adv. Water Resour., 89, 32-41, https://doi.org/10.1016/j.advwatres.2015.12.016, 2016.

Dankers, R., Arnell, N. W., Clark, D. B., Falloon, P. D., Fekete, B. M., Gosling, S. N., Heinke, J., Kim, H., Masaki, Y., Satoh, Y., Stacke, T., Wada, Y., and Wisser, D.: First look at changes in flood hazard in the Inter-Sectoral Impact Model Intercomparison Project ensemble, P. Natl. Acad. Sci. USA, 111, 3257-3261, https://doi.org/10.1073/pnas.1302078110, 2014. 
de Graaf, I. E. M., van Beek, L. P. H., Wada, Y., and Bierkens, M. F. P.: Dynamic attribution of global water demand to surface water and groundwater resources: effects of abstractions and return flows on river discharges, Adv. Water Resour., 64, 21-33, https://doi.org/10.1016/j.advwatres.2013.12.002, 2014.

de Graaf, I. E. M., Sutanudjaja, E. H., van Beek, L. P. H., and Bierkens, M. F. P.: A high-resolution global-scale groundwater model, Hydrol. Earth Syst. Sci., 19, 823-837, https://doi.org/10.5194/hess-19-823-2015, 2015.

de Graaf, I. E. M., van Beek, L. P. H., Gleeson, T., Moosdorf, N., Schmitz, O., Sutanudjaja, E. H., and Bierkens, M. F. P.: A GlobalScale Two-Layer Transient Groundwater Model: Development and Application to Groundwater Depletion, Adv. Water Resour., 102, 53-67, https://doi.org/10.1016/j.advwatres.2017.01.011, 2017.

De Lange, W. J., Prinsen, G. F., Hoogewoud, J. C., Veldhuizen, A. A., Verkaik, J., Oude Essink, G. H. P., van Walsum, P. E. V., Delsman, J. R., Hunink, J. C. Massop, H. Th. L., and Kroon, T.: An operational, multi-scale, multi-model system for consensusbased, integrated water management and policy analysis: The Netherlands Hydrological Instrument, Environ. Model. Softw., 59, 98-108, https://doi.org/10.1016/j.envsoft.2014.05.009, 2014.

De Roo, A., Wesseling, C., and Van Deursen, W.: Physically based river basin modelling within a GIS: the LISFLOOD model, Hydrol. Process., 14, 1981-1992, https://doi.org/10.1002/10991085(20000815/30)14:11/12<1981::AID-HYP49>3.0.CO;2-F, 2000.

De Roo, A., Burek, P., Gentile, A., Udias, A., Bouraoui, F., Aloe, A., Bianchi, A., La Notte, A., Kuik, O., Tenreiro, J. E., Vandecasteele, I., Mubareka, S., Baranzelli, C., Der Perk, M. V., Lavelle, C., and Bidoglio, G.: A multi-criteria optimisation of scenarios for the protection of water resources in Europe, JRC Scientific and Policy Report, JRC75919, ISSN: 1831-9424, EC-JRC-IES, Italy, 2012.

de Rosnay, P., Polcher, J., Laval, K., and Sabre, M.: Integrated parameterization of irrigation in the land surface model ORCHIDEE. Validation over Indian Peninsula, Geophys. Res. Lett., 30, 1986, https://doi.org/10.1029/2003GL018024, 2003.

Deardorff, J. W.: Efficient prediction of ground surface temperature and moisture, with inclusion of a layer of vegetation, J. Geophys. Res.-Oceans, 83, 1889-1903, https://doi.org/10.1029/JC083iC04p01889, 1978.

Di Baldassarre, G., Kooy, M., Kemerink, J. S., and Brandimarte, L.: Towards understanding the dynamic behaviour of floodplains as human-water systems, Hydrol. Earth Syst. Sci., 17, 3235-3244, https://doi.org/10.5194/hess-17-3235-2013, 2013a.

Di Baldassarre, G., Viglione, A., Carr, G., Kuil, L., Salinas, J. L., and Blöschl, G.: Socio-hydrology: conceptualising humanflood interactions, Hydrol. Earth Syst. Sci., 17, 3295-3303, https://doi.org/10.5194/hess-17-3295-2013, 2013b.

Di Baldassarre, G., Martinez, F., Kalantari, Z., and Viglione, A.: Drought and flood in the Anthropocene: feedback mechanisms in reservoir operation, Earth Syst. Dynam., 8, 225-233, https://doi.org/10.5194/esd-8-225-2017, 2017.

Dirmeyer, P. A., Gao, X. A., Zhao, M., Guo, Z. C., Oki, T. K., and Hanasaki, N.: GSWP-2 - Multimodel analysis and implications for our perception of the land surface, B. Am. Meteorol. Soc., 87, 1381-1397, https://doi.org/10.1175/BAMS-87-10-1381, 2006.
Dirmeyer, P. A., Brubaker, K. L., and DelSole, T.: Import and export of atmospheric water vapor between nations, J. Hydrol., 365, 1122, https://doi.org/10.1016/j.jhydrol.2008.11.016, 2009.

Dirmeyer, P. A., Fang, G., Wang, Z., Yadav, P., and Milton, A.: Climate change and sectors of the surface water cycle In CMIP5 projections, Hydrol. Earth Syst. Sci., 18, 5317-5329, https://doi.org/10.5194/hess-18-5317-2014, 2014.

Döll, P., Kaspar, F., and Lehner, B.: A global hydrological model for deriving water availability indicators: model tuning and validation, J. Hydrol., 270, 105-134, https://doi.org/10.1016/S00221694(02)00283-4, 2003.

Döll, P., Fiedler, K., and Zhang, J.: Global-scale analysis of river flow alterations due to water withdrawals and reservoirs, Hydrol. Earth Syst. Sci., 13, 2413-2432, https://doi.org/10.5194/hess-132413-2009, 2009.

Döll, P., Hoffmann-Dobrev, H., Portmann, F. T., Siebert, S., Eicker, A., Rodell, M., and Strassberg, G.: Impact of water withdrawals from groundwater and surface water on continental water storage variations, J. Geodyn., 59-60, 143-156, https://doi.org/10.1016/j.jog.2011.05.001, 2012.

Döll, P., Müller Schmied, H., Schuh, C., Portmann F. T., and Eicker, A.: Global-scale assessment of groundwater depletion and related groundwater abstractions: Combining hydrological modeling with information from well observations and GRACE satellites, Water Resour. Res., 50, 5698-5720, https://doi.org/10.1002/2014WR015595, 2014.

Döll, P., Douville, H., Güntner, A., Müller Schmied, H., and Wada, Y.: Modeling freshwater resources at the global scale: Challenges and prospects, Surv. Geophys., 37, 195-221, https://doi.org/10.1007/s10712-015-9343-1, 2016.

Douglas, E. M., Niyogi, D., Frolking, S., Yeluripati, J., Pielke, R. A., Niyogi, N., Vörösmarty, C., and Mohanty, U.: Changes in moisture and energy fluxes due to agricultural land use and irrigation in the Indian Monsoon Belt, Geophys. Res. Lett., 33, L14403, https://doi.org/10.1029/2006GL026550, 2006.

Ek, M. B., Mitchell, K. E., Lin, Y., Rogers, E., Grunmann, P., Koren, V., Gayno, G., and Tarpley, J. D.: Implementation of Noah land surface model advances in the National Centers for Environmental Prediction operational mesoscale Eta model, J. Geophys. Res., 108, GCP 12-1-12-16, https://doi.org/10.1029/2002JD003296, 2003

Elshafei, Y., Sivapalan, M., Tonts, M., and Hipsey, M. R.: A prototype framework for models of socio-hydrology: identification of key feedback loops and parameterisation approach, Hydrol. Earth Syst. Sci., 18, 2141-2166, https://doi.org/10.5194/hess-182141-2014, 2014.

Ertsen, M. W., Murphy, J. T., Purdue, L. E., and Zhu, T.: A journey of a thousand miles begins with one small step - human agency, hydrological processes and time in socio-hydrology, Hydrol. Earth Syst. Sci., 18, 1369-1382, https://doi.org/10.5194/hess-181369-2014, 2014.

Falkenmark, M.: The massive water scarcity now threatening Africa-why isn't it being addressed?, Ambio, 18, 112-118, 1989.

Falkenmark, M., Kijne, J. W., Taron, B., Murdoch, G., Sivakumar, M. V. K., and Craswell, E.: Meeting Water Requirements of an Expanding World Population [and Discussion], Phil. Trans. R. Soc. Lond., B. 352, 929-936, https://doi.org/10.1098/rstb.1997.0072, 1997. 
Famiglietti, J. S., Lo, M., Ho, S. L., Bethune, J., Anderson, K. J., Syed, T. H., Swenson, S. C., de Linage, C. R., and Rodell, M.: Satellites measure recent rates of groundwater depletion in California's Central Valley, Geophys. Res. Lett., 38, L03403, https://doi.org/10.1029/2010GL046442, 2011.

Famiglietti, J., Cazenave, A., Eicker, A., Reager, J., Rodell, M., and Velicogna, I.: Satellites provide the big picture, Science, 349 , 684-685, https://doi.org/10.1126/science.aac9238, 2015.

Fan, Y., Li, H., and Miguez-Macho, G.: Global Patterns of Groundwater Table Depth, Science, 339, 940-943, https://doi.org/10.1126/science.1229881, 2013.

Fan, Y., Richard, S., Bristol, R. S., Peters, S. E., Ingebritsen, S. E., Moosdorf, N., Packman, A., Gleeson, T., Zaslavsky, I., Peckham, S., Murdoch, L., Fienen, M., Cardiff, M., Tarboton, D., Jones, N., Hooper, R., Arrigo, J., Gochis, D., Olson, J., and Wolock, D.: DigitalCrust - a 4D data system of material properties for transforming research on crustal fluid flow, Geofluids, 15, 372379, https://doi.org/10.1111/gfl.12114, 2015.

Federer, C. A., Vörösmarty, C., and Fekete, B.: Intercomparison of methods for calculating potential evaporation in regional global water balance models, Water Resour. Res., 32, 23152321, https://doi.org/10.1029/96WR00801, 1996.

Federer, C. A., Vörösmarty, C., and Fekete, B.: Sensitivity of annual evaporation to soil and root properties in two models of contrasting complexity, J. Hydrometeorol., 4, 1276-1290, https://doi.org/10.1175/15257541(2003)004<1276:SOAETS>2.0.CO;2, 2003.

Fekete, B. M., Robarts, R. D., Kumagai, M., Nachtnebel, H.-P., Odada, E., and Zhulidov, A. V.: Time for in situ renaissance, Science, 349, 685-686, https://doi.org/10.1126/science.aac7358, 2015.

Ferguson, I. M. and Maxwell, R. M.: Human impacts on terrestrial hydrology: climate change versus pumping and irrigation, Environ. Res. Lett., 7, 044022, https://doi.org/10.1088/17489326/7/4/044022, 2012.

Flörke, M., Kynast, E., Bärlund, I., Eisner, S., Wimmer, F., and Alcamo, J.: Domestic and industrial water uses of the past 60 years as a mirror of socio-economic development: A global simulation study, Global Environ. Chang., 23, 144-156, https://doi.org/10.1016/j.gloenvcha.2012.10.018, 2013.

Forzieri, G., Feyen, L., Rojas, R., Flörke, M., Wimmer, F., and Bianchi, A.: Ensemble projections of future streamflow droughts in Europe, Hydrol. Earth Syst. Sci., 18, 85-108, https://doi.org/10.5194/hess-18-85-2014, 2014.

Gao, H.: Satellite remote sensing of large lakes and reservoirs: From elevation and area to storage, Wiley Interdiscip. Rev.-Water, 2, 147-157, https://doi.org/10.1002/wat2.1065, 2015.

Gerten, D., Schaphoff, S., and Lucht, W.: Potential future changes in water limitation of the terrestrial biosphere, Clim. Change, 80 , 277-299, https://doi.org/10.1007/s10584-006-9104-8, 2007.

Gleeson, T., Wada, Y., Bierkens, M. F. P., and van Beek, L. P. H.: Water balance of global aquifers revealed by groundwater footprint, Nature, 488, 197-200, https://doi.org/10.1038/nature11295, 2012.

Gleeson, T., Moosdorf, N., Hartmann, J., and van Beek, L. P. H.: A glimpse beneath earth's surface: Global hydrogeology maps (GLHYMPS) of permeability and porosity, Geophys. Res. Lett., 41, 3891-3898, https://doi.org/10.1002/2014GL059856, 2014.
Gleick, P. H.: The changing water paradigm: a look at twenty-first century water resources development, Water Inter., 25, 127-138, https://doi.org/10.1080/02508060008686804, 2000.

Gleick, P.: Global Freshwater Resources: Soft Path Solutions for the 21st Century, Science, 302, 1524-1528, https://doi.org/10.1126/science.1089967, 2003.

Gleick, P. H., Cooley, H., Famiglietti, J. S., Lettenmaier, D. P., Oki, T., Vörösmarty, C. J., and Wood, E. F.: Improving Understanding of the Global Hydrologic Cycle, in: Climate Science for Serving Society, edited by: Asrar, G. R. and Hurrell, J. W., Springer Netherlands, 151-184, https://doi.org/10.1007/978-94007-6692-1, 2013.

Gober, P. and Wheater, H. S.: Debates - perspectives on sociohydrology: Modeling flood risk as a public policy problem, Water Resour. Res., 51, 4782-4788, https://doi.org/10.1002/2015WR016945, 2015.

Gordon, L. J., Steffen, W., Jonsson, B. F., Folke, C., Falkenmark, M., and Johannessen, A.: Human Modification of global water vapor flows from the land surface, P. Natl. Acad. Sci. USA, 102, 7612-7617, https://doi.org/10.1073/pnas.0500208102, 2005.

Gosling, S. N. and Arnell, N. W.: A global assessment of the impact of climate change on water scarcity, Clim. Change, 134, 371385, https://doi.org/10.1007/s10584-013-0853-x, 2016.

Gosling, S. N., Zaherpour, J. J., Mount, N. J., Hattermann, F. F., Dankers, R., Arheimer, B., Breuer, L., Ding, J., Haddeland, I., Kumar, R., Kundu, D., Liu, J., van Griensven, A., Veldkamp, T. I. E., Vetter, T., Wang, X., and Zhang, X.: A comparison of changes in river runoff from multiple global and catchment-scale hydrological models under global warming scenarios of $1^{\circ} \mathrm{C}, 2^{\circ} \mathrm{C}$ and $3^{\circ} \mathrm{C}$, Climate Change, 14, 577-595, https://doi.org/10.1007/s10584-016-1773-3, 2017.

Güneralp, B., Güneralp, I., and Liu, Y.: Changing global patterns of urban exposure to flood and drought hazards, Glob. Environ. Chang., 31, 217-225, https://doi.org/10.1016/j.gloenvcha.2015.01.002, 2015.

Haddeland, I., Clark, D. B., Franssen, W., Ludwig, F., Voß, F., Arnell, N. W., Bertrand, N., Best, M., Folwell, S., Gerten, D., Gomes, S., Gosling, S. N., Hagemann, S., Hanasaki, N., Harding, R., Heinke, J., Kabat, P., Koirala, S., Oki, T., Polcher, J., Stacke, T., Viterbo, P., Weedon, G. P., and Yeh, P.: Multimodel Estimate of the Global Terrestrial Water Balance: Setup and First Results, J. Hydromet., 12, 869-884, https://doi.org/10.1175/2011jhm1324.1, 2011.

Haddeland, I., Heinke, J, Biemans, H., Eisnere, S., Flörkee, M., Hanasaki, N., Konzmann, M., Ludwig, F., Masaki, Y., Schewe, J., Stacke, T., Tessler, Z. D., Wada, Y., and Wisser, D.: Global water resources affected by human interventions and climate change, P. Natl. Acad. Sci. USA, 111, 3251-3256, https://doi.org/10.1073/pnas.1222475110, 2014.

Hagemann, S., Chen, C., Clark, D. B., Folwell, S., Gosling, S. N., Haddeland, I., Hanasaki, N., Heinke, J., Ludwig, F., Voss, F., and Wiltshire, A. J.: Climate change impact on available water resources obtained using multiple global climate and hydrology models, Earth Syst. Dynam., 4, 129-144, https://doi.org/10.5194/esd-4-129-2013, 2013.

Halder, S., Saha, S. K., Dirmeyer, P. A., Chase, T. N., and Goswami, B. N.: Investigating the impact of land-use land-cover change on Indian summer monsoon daily rainfall and temperature during 1951-2005 using a regional climate model, Hydrol. Earth Syst. 
Sci., 20, 1765-1784, https://doi.org/10.5194/hess-20-1765-2016, 2016.

Hanasaki, N., Kanae, S., and Oki, T.: A reservoir operation scheme for global river routing models, J. Hydrol., 327, 22-41, https://doi.org/10.1016/j.jhydrol.2005.11.011, 2006.

Hanasaki, N., Kanae, S., Oki, T., Masuda, K., Motoya, K., Shirakawa, N., Shen, Y., and Tanaka, K.: An integrated model for the assessment of global water resources - Part 1: Model description and input meteorological forcing, Hydrol. Earth Syst. Sci., 12, 1007-1025, https://doi.org/10.5194/hess-12-1007-2008, 2008a.

Hanasaki, N., Kanae, S., Oki, T., Masuda, K., Motoya, K., Shirakawa, N., Shen, Y., and Tanaka, K.: An integrated model for the assessment of global water resources - Part 2: Applications and assessments, Hydrol. Earth Syst. Sci., 12, 1027-1037, https://doi.org/10.5194/hess-12-1027-2008, 2008 b.

Hanasaki, N., Inuzuka, T., Kanae, S., and Oki, T.: An estimation of global virtual water flow and sources of water withdrawal for major crops and livestock products using a global hydrological model, J. Hydrol., 384, 232-244, https://doi.org/10.1016/j.jhydrol.2009.09.028, 2010.

Hanasaki, N., Saito, Y., Chaiyasaen, C., Champathong, A., Ekkawatpanit, C., Saphaokham, S., Sukhapunnaphan, T., Sumdin, S., and Thongduang, J.: A quasi-real-time hydrological simulation of the Chao Phraya River using meteorological data from the Thai Meteorological Department Automatic Weather Stations, Hydrolg. Res. Lett., 8, 9-14, https://doi.org/10.3178/hrl.8.9, 2014.

Hanasaki, N., Yoshikawa, S., Kakinuma, K., and Kanae, S.: A seawater desalination scheme for global hydrological models, Hydrol. Earth Syst. Sci., 20, 4143-4157, https://doi.org/10.5194/hess-20-4143-2016, 2016.

Hannah, D. M., Demuth, S., van Lanen, H. A. J., Looser, U., Prudhomme, C., Rees, R., Stahl, K., and Tallaksen, L. M.: Large-scale river flow archives: importance, current status and future needs, Hydrol. Process., 25, 1191-1200, https://doi.org/10.1002/hyp.7794, 2011.

Harding, R. J., Weedon, G. P., Van Lanen, H. A. J., and Clark, D. B.: The future for global water assessment, J. Hydrol., 518, 186193, https://doi.org/10.1016/j.jhydrol.2014.05.014, 2014.

Hattermann, F. F., Krysanova, V., Gosling, S., Dankers, R., Daggupati, P., Donnelly, Ch., Flörke, M., Huang, Sh., Motovilov, Yu., Buda, Su., Yang, T., Müller, C., Leng, G., Tang, Q., Portmann, F. T., Hagemann, S., Gerten, D., Wada, Y., Masaki, Y., Alemayehu, T., Satoh, Y., and Samaniego, L.: Cross-scale intercomparison of climate change impacts simulated by regional and global hydrological models in eleven large river basins, Clim. Change, 141, 561-576, https://doi.org/10.1007/s10584-016-1829-4, 2017.

He, X., Wada, Y., Wanders, N., and Sheffield, J.: Intensification of hydrological drought in California by human water management, Geophys. Res. Lett., 44, 1777-1785, https://doi.org/10.1002/2016GL071665, 2017.

Hejazi, M., Edmonds, J., Chaturvedi, V., Davies, E., and Eom, J. Y.: Scenarios of global municipal water use demand projections over the 21st century, Hydrol. Sci. J., 58, 519-538, 2013a.

Hejazi, M., Edmonds, J., Clarke, L., Kyle, P., Chaturvedi, V., Davies, E., Wise, M., Patel, P., Eom, J., and Calvin, K.: Long-term global water use projections using six socioeconomic scenarios in an integrated assessment modeling framework, Technol. Forecast. Social Change, 81, 205-226, https://doi.org/10.1016/j.techfore.2013.05.006, 2013b.

Hejazi, M. I., Edmonds, J., Clarke, L., Kyle, P., Davies, E., Chaturvedi, V., Wise, M., Patel, P., Eom, J., and Calvin, K.: Integrated assessment of global water scarcity over the 21st century under multiple climate change mitigation policies, Hydrol. Earth Syst. Sci., 18, 2859-2883, https://doi.org/10.5194/hess-18-28592014, 2014.

Hisdal, H., Stahl, K., Tallaksen, L. M., and Demuth, S.: Have droughts in Europe become more severe or frequent?, Int. J. Climatol., 21, 317-333, https://doi.org/10.1002/joc.619, 2001.

Hirabayashi, Y., Mahendran, R., Koirala, S., Konoshima, L., Yamazaki, D., Watanabe, S., Kim, H., and Kanae, S.: Global 20 flood risk under climate change, Nature Clim. Change, 3, 816821, https://doi.org/10.1038/nclimate1911, 2013.

Hoekstra, A. Y.: Human appropriation of natural capital: A comparison of ecological footprint and water footprint analysis, Ecol. Econ., 68, 1963-1974, https://doi.org/10.1016/j.ecolecon.2008.06.021, 2009.

Hoekstra, A. Y. and Chapagain, A. K.: Water footprints of nations: water use by people as a function of their consumption pattern, Water Resour. Manag., 21, 35-48, https://doi.org/10.1007/s11269-006-9039-x, 2007.

Hoekstra, A. Y. and Mekonnen, M. M.: The water footprint of humanity, P. Natl. Acad. Sci. USA, 109, 3232-3237, https://doi.org/10.1073/pnas.1109936109, 2012.

Hogue, T. S., Bastidas, L. A., Gupta, H. V., and Sorooshian, S.: Evaluating model performance and parameter behavior for varying levels of land surface model complexity, Water Resour. Res., 42, W08430, https://doi.org/10.1029/2005WR004440, 2006.

Huffman, G. J., Adler, R. F., Bolvin, D. T., Gu, G., Nelkin, E. J., Bowman, K. P., Hong, Y., Stocker, E. F., and Wolff, D. B.: The TRMM Multi-satellite Precipitation Analysis (TMPA): Quasiglobal, multiyear, combined sensor precipitation estimates at fine scales, J. Hydrometeorol., 8, 38-55, https://doi.org/10.1175/JHM560.1, 2007.

Hydrology Group: Department of Physical Geography, Utrecht University, PCR-GLOBWB 2.0, available at: http://www. globalhydrology.nl/models/pcr-globwb-2-0/, 2017.

Jacobson, C. R.: Identification and quantification of the hydrological impacts of imperviousness in urban catchments: A review, J. Environ. Manage., 92, 1438-1448, https://doi.org/10.1016/j.jenvman.2011.01.018, 2011.

Jongman, B., Ward, P. J., and Aerts, J. C. J. H.: Global exposure to river and coastal flooding: Long term trends and changes, Glob. Environ. Chang., 22, 823-835, https://doi.org/10.1016/j.gloenvcha.2012.07.004, 2012.

Jongman, B., Hochrainer-Stigler, S., Feyen, L., Aerts, J. C. J. H., Mechler, R., Botzen, W. J. W., Bouwer, L. M., Pflug, G., Rojas, R., and Ward, P. J.: Increasing stress on disaster-risk finance due to large floods, Nat. Clim. Change, 4, 264-268, https://doi.org/10.1038/nclimate2124, 2014.

Kandasamy, J., Sounthararajah, D., Sivabalan, P., Chanan, A., Vigneswaran, S., and Sivapalan, M.: Socio-hydrologic drivers of the pendulum swing between agricultural development and environmental health: a case study from Murrumbidgee River basin, Australia, Hydrol. Earth Syst. Sci., 18, 1027-1041, https://doi.org/10.5194/hess-18-1027-2014, 2014. 
King Abdullah University of Science and Technology Industry Collaboration Program (KICP): Promoting Wastewater Reclamation and Reuse in the Kingdom of Saudi Arabia: Technology Trends, Innovation Needs, and Business Opportunities, King Abdullah University of Science and Technology, Thuwal, Saudi Arabia, 2011

Klein Goldewijk, K., Beusen, A., van Drecht, G., and de Vos, M.: The HYDE 3.1 spatially explicit database of human-induced global land-use change over the past 12000 years, Global Ecol. Biogeogr., 20, 73-86, https://doi.org/10.1111/j.14668238.2010.00587.x, 2011.

Konikow, L. F.: Contribution of global groundwater depletion since 1900 to sea-level rise, Geophys. Res. Lett., 38, L17401, https://doi.org/10.1029/2011GL048604, 2011.

Konzmann, M., Gerten, D., and Heinke, J.: Climate impacts on global irrigation requirements under $19 \mathrm{GCMs}$, simulated with a vegetation and hydrology model, Hydrolog. Sci. J., 58, 1-18, https://doi.org/10.1080/02626667.2013.746495, 2013.

Koster, R. D., Dirmeyer, P. A., Guo, Z., Bonan, G., Chan, E., Cox, P., Gordon, C. T., Kanae, S., Kowalczyk, E., Lawrence, D., Liu, P., Lu, C.-H., Malyshev, S., McAvaney, B., Mitchell, K., Mocko, D., Oki, T., Oleson, K., Pitman, A., Sud, Y. C., Taylor, C. M., Verseghy, D., Vasic, R., Xue, Y., and Yamada, T.: Regions of Strong Coupling Between Soil Moisture and Precipitation, Science, 305, 1138-1140, https://doi.org/10.1126/science.1100217, 2004.

Krebs, G., Kokkonen, T., Valtanen, M., Setälä, H., and Koivusalo, H.: Spatial resolution considerations for urban hydrological modelling, J. Hydrol., 512, 482-497, https://doi.org/10.1016/j.jhydrol.2014.03.013, 2014.

Kummu, M., Ward, P. J., de Moel, H., and Varis, O.: Is physical water scarcity a new phenomenon? Global assessment of water shortage over the last two millennia, Environ. Res. Lett., 5, 034006, https://doi.org/10.1088/1748-9326/5/3/034006, 2010.

Kummu, M., Gerten, D., Heinke, J., Konzmann, M., and Varis, O.: Climate-driven interannual variability of water scarcity in food production potential: a global analysis, Hydrol. Earth Syst. Sci., 18, 447-461, https://doi.org/10.5194/hess-18-447-2014, 2014.

Lauri, H., de Moel, H., Ward, P. J., Räsänen, T. A., Keskinen, M., and Kummu, M.: Future changes in Mekong River hydrology: impact of climate change and reservoir operation on discharge, Hydrol. Earth Syst. Sci., 16, 4603-4619, https://doi.org/10.5194/hess-16-4603-2012, 2012.

Lawford, R., Strauch, A., Toll, D., Fekete, B., and Cripe, D.: Earth observations for global water security, Curr. Opin. Environ. Sustain., 5, 633-643, https://doi.org/10.1016/j.cosust.2013.11.009, 2013

Lawrence, D. M., Oleson, K. W., Flanner, M. G., Thornton, P. E., Swenson, S. C., Lawrence, P. J., Zeng, X., Yang, Z.-L., Levis, S., Sakaguchi, K., Bonan, G. B., and Slater, A. G.: Parameterization improvements and functional and structural advances in Version 4 of the Community Land Model, J. Adv. Model. Earth Sys., 3, M03001, https://doi.org/10.1029/2011MS00045, 2011.

Levy, M. C., Garcia, M., Blair, P., Chen, X., Gomes, S. L., Gower, D. B., Grames, J., Kuil, L., Liu, Y., Marston, L., McCord, P. F., Roobavannan, M., and Zeng, R.: Wicked but worth it: student perspectives on socio-hydrology, Hydrol. Process., 30, 14671472, https://doi.org/10.1002/hyp.10791, 2016.
Lehner, B., Liermann, C. R., Revenga, C., Vörösmarty, C., Fekete, B., Crouzet, P., Döll, P., Endejan, M., Frenken, K., Magome, J., Nilsson, C., Robertson, J. C., Rödel, R., Sindorf, N., and Wisser, D.: High-resolution mapping of the world's reservoirs and dams for sustainable river-flow management, Front. Ecol. Environ., 9, 494-502, https://doi.org/10.1890/100125, 2011.

Leng, G., Huang, M., Tang, Q., Gao, H., and Leung, L. R.: Modeling the Effects of Groundwater-Fed Irrigation on Terrestrial Hydrology over the Conterminous United States, J. Hydrometeor., 15, 957-972, https://doi.org/10.1175/JHM-D-13-049.1, 2014.

Leng, G., Huang, M., Tang, Q., and Leung, L. R.: A modeling study of irrigation effects on global surface water and groundwater resources under a changing climate, J. Adv. Model. Earth Sys., 7, 1285-1304, https://doi.org/10.1002/2015MS000437, 2015.

Lettenmaier, D. P. and Famiglietti, J. S.: Hydrology: Water from on high, Nature, 444, 562-563, https://doi.org/10.1038/444562a, 2006.

Lins, H. F. and Slack, J. R.: Streamflow trends in the United States, Geophys. Res. Lett., 26, 227-230, https://doi.org/10.1029/1998GL900291, 1999.

Liu, J., Zhao, D., Gerbens-Leenes, P. W., and Guan, D.: China's rising hydropower demand challenges water sector, Sci. Rep., 5, 11446, https://doi.org/10.1038/srep11446, 2015.

Liu, J., Liu, Q., and Yang, H.: Assessing water scarcity by simultaneously considering environmental flow requirements, water quantity, and water quality, Ecol. Indic., 60, 434-441, https://doi.org/10.1016/j.ecolind.2015.07.019, 2016.

Liu, J., Yang, H., Gosling, S. N., Kummu, M., Flörke, M., Pfister, M., Hanasaki, N., Wada, Y., Zhang, X., Zheng, Y., Alcamo, J., and Oki, T.: Water scarcity assessments in the past, present, and future, Earth's Future, 5, 545-559, https://doi.org/10.1002/2016EF000518, 2017.

Liu, Y., Tian, F., Hu, H., and Sivapalan, M.: Socio-hydrologic perspectives of the co-evolution of humans and water in the Tarim River basin, Western China: the Taiji-Tire model, Hydrol. Earth Syst. Sci., 18, 1289-1303, https://doi.org/10.5194/hess-18-12892014, 2014.

Lo, M.-H. and Famiglietti, J. S.: Irrigation in California's Central Valley strengthens the southwestern U.S. water cycle, Geophy. Res. Lett., 40, 301-306, https://doi.org/10.1002/grl.50108, 2013.

Longuevergne, L., Scanlon, B. R., and Wilson, C. R.: GRACE Hydrological estimates for small basins: Evaluating processing approaches on the High Plains Aquifer, USA, Water Resour. Res. 46, W11517, https://doi.org/10.1029/2009WR008564, 2010.

Lopez, S. R. and Maxwell, R. M.: Identifying Urban Features from LiDAR for a High-Resolution Urban Hydrologic Model, J. Am. Water Resour. Assoc., 52, 756-768, https://doi.org/10.1111/1752-1688.12425, 2016.

Loucks, D. P.: Debates - Perspectives on socio-hydrology: Simulating hydrologic-human interactions, Water Resour. Res., 51, 4789-4794, https://doi.org/10.1002/2015WR017002, 2015.

Manabe, S.: Climate and the ocean circulation1, Mon. Weather Rev., 97, 739-774, https://doi.org/10.1175/1520 0493(1969)097<0739:CATOC>2.3.CO;2, 1969.

Masood, M., Yeh, P. J.-F., Hanasaki, N., and Takeuchi, K.: Model study of the impacts of future climate change on the hydrology of Ganges-Brahmaputra-Meghna basin, Hydrol. Earth Syst. Sci., 19, 747-770, https://doi.org/10.5194/hess-19-747-2015, 2015. 
Mateo, C. M., Hanasaki, N., Komori, D., Tanaka, K., Kiguchi, M., Champathong, A., Sukhapunnaphan, T., Yamazaki, D., and Oki, T.: Assessing the impacts of reservoir operation to floodplain inundation by combining hydrological, reservoir management, and hydrodynamic models, Water Resour. Res., 50, 7245-7266, https://doi.org/10.1002/2013wr014845, 2014.

Masaki, Y., Hanasaki, N., Biemans, H., Müller Schmied, H., Tang, Q., Wada, Y., Gosling, S. N., Takahashi, K., and Hijioka, Y.: Intercomparison of global river discharge simulations focusing on dam operation - multiple models analysis in two casestudy river basins, Missouri-Mississippi and Green-Colorado, Environ. Res. Lett., 12, 055002, https://doi.org/10.1088/17489326/aa57a8, 2017.

McDonald, R. I., Weber, K., Padowski, J., Flörke, M., Schneider, C., Green, P. A., Gleeson, T., Eckman, S., Lehner, B., Balk, D., Boucher, T., Grill, G., and Montgomery, M.: Water on an urban planet: Urbanization and the reach of urban water infrastructure, Glob. Environ. Chang., 27, 96-105, https://doi.org/10.1016/j.gloenvcha.2014.04.022, 2014.

McMillan, H., Montanari, A., Cudennec, C., Savenije, H., Kreibich, H., Krueger, T., Liu, J., Mejia, A., Van Loon, A. F., Aksoy, H., Di Baldassarre, G., Huang, Y., Mazvimavi, D., Rogger, M., Sivakumar, B., Bibikova, T., Castellarin, A., Chen, Y., Finger, D., Gelfan, A., Hannah, D., Hoekstra, A., Li, H., Maskey, S., Mathevet, T., Mijic, A., Pedrozo Acuña, A., Polo, M., Rosales, V., Smith, P., Viglione, A., Srinivasan, V., Toth, E., van Nooyen, R., and Xia, J.: Panta Rhei 2013-2015: global perspectives on hydrology, society and change, Hydrol. Sci. J., 61, 1174-1191, https://doi.org/10.1080/02626667.2016.1159308, 2016.

Melsen, L. A., Teuling, A. J., Torfs, P. J. J. F., Uijlenhoet, R., Mizukami, N., and Clark, M. P.: HESS Opinions: The need for process-based evaluation of large-domain hyperresolution models, Hydrol. Earth Syst. Sci., 20, 1069-1079, https://doi.org/10.5194/hess-20-1069-2016, 2016.

Milly, P. C. D., Dunne, K. A., and Vecchia, A. V.: Global pattern of trends in streamflow and water availability in a changing climate, Nature, 438, 347-350, https://doi.org/10.1038/nature04312, 2005.

Milly, P. C. D., Betancourt, J., Falkenmark, M., Hirsch, R. M., Kundzewicz, Z. W., Lettenmaier, D. P., and Stouffer, R. J.: Stationarity Is Dead: Whither Water Management?, Science, 319, 573-574, https://doi.org/10.1126/science.1151915, 2008.

Montanari, A., Young, G., Savenije, H. H. G., Hughes, D., Wagener, T., Ren, L. L., Koutsoyiannis, D., Cudennec, C., Toth, E., Grimaldi, S., Blöschl, G., Sivapalan, M., Beven, K., Gupta, H., Hipsey, M., Schaefli, B., Arheimer, B., Boegh, E., Schymanski, S. J., Di Baldassarre, G., Yu, B., Hubert, P., Huang, Y., Schumann, A., Post, D., Srinivasan, V., Harman, C., Thompson, S., Rogger, M., Viglione, A., McMillan, H., Characklis, G., Pang, Z., and Belyaev, V.: "Panta Rhei - Everything Flows": Change in hydrology and society - The IAHS Scientific Decade 20132022, Hydrol. Sci. J., 58, 1256-1275, 2013.

Mount, N. J., Maier, H. R., Toth, E., Elshorbagy, A., Solomatine, D., Chang, F.-J., and Abrahart, R. J.: Data-driven modeling approaches for socio-hydrology: opportunities and challenges within the Panta Rhei Science Plan. Hydrol. Sci. J., 58, 1192 1208, https://doi.org/10.1080/02626667.2016.1159683, 2016.

Mu, Q., Zhao, M., and Running, S. W.: Improvements to a MODIS global terrestrial evapotranspiration al- gorithm, Remote Sens. Environ., 115, 1781-1800, https://doi.org/10.1016/j.rse.2011.02.019, 2011.

Muis, S., Güneralp, B., Jongman, B., Aerts, J. C. J. H., and Ward, P. J.: Flood risk and adaptation strategies under climate change and urban expansion: A probabilistic analysis using global data, Sci. Total Environ., 538, 445-457, https://doi.org/10.1016/j.scitotenv.2015.08.068, 2015.

Müller Schmied, H., Eisner, S., Franz, D., Wattenbach, M., Portmann, F. T., Flörke, M., and Döll, P.: Sensitivity of simulated global-scale freshwater fluxes and storages to input data, hydrological model structure, human water use and calibration, Hydrol. Earth Syst. Sci., 18, 3511-3538, https://doi.org/10.5194/hess-18-3511-2014, 2014.

Munia, H., Guillaume, J. H. A., Mirumachi, N., Porkka, M., Wada, Y., and Kummu, M.: Water stress in global transboundary river basins: significance of upstream water use on downstream stress, Environ. Res. Lett., 11, 014002, https://doi.org/10.1088/17489326/11/1/014002, 2016.

Nazemi, A. and Wheater, H. S.: On inclusion of water resource management in Earth system models - Part 2: Representation of water supply and allocation and opportunities for improved modeling, Hydrol. Earth Syst. Sci., 19, 63-90, https://doi.org/10.5194/hess-19-63-2015, 2015a.

Nazemi, A. and Wheater, H. S.: On inclusion of water resource management in Earth system models - Part 1: Problem definition and representation of water demand, Hydrol. Earth Syst. Sci., 19, 33-61, https://doi.org/10.5194/hess-19-33-2015, 2015b.

Nijssen, B., Schnur, R., and Lettenmaier, D. P.: Global retrospective estimation of soil moisture using the variable infiltration capacity land surface model, 1980-93, J. Climate, 14, 1790-1808, https://doi.org/10.1175/15200442(2001)014<1790:GREOSM>2.0.CO;2, 2001a.

Nijssen, B., O'Donnell, G. M., Lettenmaier, D. P., Lohmann, D., and Wood, E. F.: Predicting the discharge of global rivers, J. Climate, 14, 3307-3323, https://doi.org/10.1175/15200442(2001)014<3307:PTDOGR>2.0.CO;2, $2001 \mathrm{~b}$.

Nilsson, C., Reidy, C. A., Dynesius, M., and Revenga, C.: Fragmentation and flow regulation of the world's large river systems, Science, 308, 405-408, https://doi.org/10.1126/science.1107887, 2005.

Oki, T. and Kanae, S.: Virtual water trade and world water resources, Water Sci. Technol., 49, 203-209, 2004.

Oki, T. and Kanae, S.: Global hydrological cycles and world water resources, Science, 313, 1068-1072, https://doi.org/10.1126/science.1128845, 2006.

Oki, T. and Sud, Y. C.: Design of Total Integrating Pathways (TRIP) - a global river channel network, Earth Interact., 2, 1-36, https://doi.org/10.1175/10873562(1998)002<0001:DOTRIP>2.3.CO;2, 1998.

Oki, T., Nishimura, T., and Dirmeyer, P.: Assessment of annual runoff from land surface models using Total Runoff Integrating Pathways (TRIP), J. Meteorol. Soc. Jpn., 77, 235-255, 1999.

Oki, T., Agata, Y., Kanae, S., Saruhashi, T., Yang, D. W., and Musiake, K.: Global assessment of current water resources using total runoff integrating pathways, Hydrolog. Sci. J., 46, 983-995, https://doi.org/10.1080/02626660109492890, 2001.

Oki, T., Yano, S., and Hanasaki, N.: Economic aspects of virtual water trade, Environ. Res. Lett., 12, 044002, https://doi.org/10.1088/1748-9326/aa625f, 2017. 
Orlowsky, B. and Seneviratne, S. I.: Elusive drought: uncertainty in observed trends and short- and long-term CMIP5 projections, Hydrol. Earth Syst. Sci., 17, 1765-1781, https://doi.org/10.5194/hess-17-1765-2013, 2013.

Osborne, T., Gornall, J., Hooker, J., Williams, K., Wiltshire, A., Betts, R., and Wheeler, T.: JULES-crop: a parametrisation of crops in the Joint UK Land Environment Simulator, Geosci. Model Dev., 8, 1139-1155, https://doi.org/10.5194/gmd-8-11392015, 2015.

Overgaard, J., Rosbjerg, D., and Butts, M. B.: Land-surface modelling in hydrological perspective - a review, Biogeosciences, 3, 229-241, https://doi.org/10.5194/bg-3-229-2006, 2006.

Ozdogan, M., Rodell, M., Beaudoing, H. K., and Toll, D. L.: Simulating the Effects of Irrigation over the United States in a Land Surface Model Based on SatelliteDerived Agricultural Data, J. Hydrometeorol., 11, 171-184, https://doi.org/10.1175/2009JHM1116.1, 2010.

Pande, S. and Ertsen, M.: Endogenous change: on cooperation and water availability in two ancient societies, Hydrol. Earth Syst. Sci., 18, 1745-1760, https://doi.org/10.5194/hess-18-1745-2014, 2014.

Pande, S. and Sivapalan, M.: Progress in socio-hydrology: a metaanalysis of challenges and opportunities, Wiley Interdiscip. Rev. Water., 4, e1193, https://doi.org/10.1002/wat2.1193, 2016.

Pastor, A. V., Ludwig, F., Biemans, H., Hoff, H., and Kabat, P.: Accounting for environmental flow requirements in global water assessments, Hydrol. Earth Syst. Sci., 18, 5041-5059, https://doi.org/10.5194/hess-18-5041-2014, 2014.

Poff, N. L., Richter, B., Arthington, A. H., Bunn, S. E., Naiman, R. J., Kendy, E., Acreman, M., Apse, C., Bledsoe, B. P., Freeman, M., Henriksen, J., Jacobson, R. B., Kennen, J., Merritt, D. M., O'Keeffe, J., Olden, J. D., Rogers, K., Tharme, R. E., and Warner, A.: The ecological limits of hydrologic alteration (ELOHA): a new framework for developing regional environmental flow standards, Freshwater Biol., 55, 147-170, https://doi.org/10.1111/j.1365-2427.2009.02204.x, 2010.

Pokhrel, Y., Hanasaki, N., Koirala, S., Cho, J., Yeh, P. J. F., Kim, H., Kanae, S., and Oki, T.: Incorporating Anthropogenic Water Regulation Modules into a Land Surface Model, J. Hydromet., 13, 255-269, https://doi.org/10.1175/jhm-d-11-013.1, 2012.

Pokhrel, Y. N., Koirala, S., Yeh, P. J.-F., Hanasaki, N., Longuevergne, L., Kanae, S., and Oki, T.: Incorporation of groundwater pumping in a global Land Surface Model with the representation of human impacts, Water Resour. Res., 51, 78-96, https://doi.org/10.1002/2014WR015602, 2015.

Pokhrel, Y. N., Hanasaki, N., Wada, Y., and Kim, H.: Recent progresses in incorporating human land-water management into global land surface models toward their integration into Earth system models, Wiley Interdisc. Rev.-Water, 3, 548-574, https://doi.org/10.1002/wat2.1150, 2016.

Prudhomme, C., Giuntoli, I., Robinson, E. L., Clark, D. B., Arnell, N. W., Dankers, R., Fekete, B. M., Franssen, W., Gerten, D., Gosling, S. N., Hagemann, S., Hannah, D. M., Kim, H., Masaki, Y., Satoh, Y., Stacke, T., Wada, Y., and Wisser, D.: Hydrological droughts in the 21st century, hotspots and uncertainties from a global multimodel ensemble experiment, P. Natl. Acad. Sci. USA, 111, 3262-3267, https://doi.org/10.1073/pnas.1222473110, 2014.
Puma, M. J. and Cook, B. I.: Effects of irrigation on global climate during the 20th century, J. Geophys. Res., 115, D16120, https://doi.org/10.1029/2010JD014122, 2010.

Renner, M., Brust, K., Schwärzel, K., Volk, M., and Bernhofer, C.: Separating the effects of changes in land cover and climate: a hydro-meteorological analysis of the past $60 \mathrm{yr}$ in Saxony, Germany, Hydrol. Earth Syst. Sci., 18, 389-405, https://doi.org/10.5194/hess-18-389-2014, 2014.

Reyes, B., Maxwell, R. M., and Hogue, T. S.: Impact of lateral flow and spatial scaling on the simulation of semi-arid urban land surfaces in an integrated hydrologic and land surface model, Hydrol Process., 30, 1192-1207, https://doi.org/10.1002/hyp.10683, 2016.

Rodell, M., Velicogna, I., and Famiglietti, J. S.: Satellite-based estimates of groundwater depletion in India, Nature, 460, 999-1002, https://doi.org/10.1038/nature08238, 2009.

Rost, S., Gerten, D., Bondeau, A., Lucht, W., Rohwer, J., and Schaphoff, S.: Agricultural green and blue water consumption and its influence on the global water system, Water Resour. Res., 44, W09405, https://doi.org/10.1029/2007WR006331, 2008.

Sacks, W. J., Cook, B. I., Buenning, N., Levis, S., and Helkowski, J. H.: Effects of global irrigation on the near-surface climate, Clim. Dynam., 33, 159-175, https://doi.org/10.1007/s00382008-0445-z, 2009.

Sampson, C. C., Smith, A. M., Bates, P. D., Neal, J. C., Alfieri, L., and Freer, J. E.: A high-resolution global flood hazard model, Water Resour. Res., 51, 7358-7381, https://doi.org/10.1002/2015WR016954, 2015.

Savenije, H. H. G., Hoekstra, A. Y., and van der Zaag, P.: Evolving water science in the Anthropocene, Hydrol. Earth Syst. Sci., 18, 319-332, https://doi.org/10.5194/hess-18-319-2014, 2014.

Scanlon, B. R., Keese, K. E., Flint, A. L., Flint, L. E., Gaye, C. B., Edmunds, W. M., and Simmers, I.: Global synthesis of groundwater recharge in semiarid and arid regions, Hydrol. Process., 20, 3335-3370, https://doi.org/10.1002/hyp.6335, 2006.

Scanlon, B. R., Faunt, C. C., Longuevergne, L., Reedy, R. C., Alley, W. M., McGuire, V. L., and McMahon, P. B.: Groundwater depletion and sustainability of irrigation in the US High Plains and Central Valley, P. Natl. Acad. Sci. USA, 109, 9320-9325, https://doi.org/10.1073/pnas.1200311109, 2012.

Schewe, J., Heinke, J., Gerten, D., Haddeland, I., Arnell, N. W., Clark, D. B., Dankers, R., Eisner, S., Fekete, B. M., ColónGonzález, F. J., Gosling, S. N., Kim, H., Liu, X., Masaki, Y., Portmann, F. T., Satoh, Y., Stacke, T., Tang, Q., Wada, Y., Wisser, D., Albrecht, T., Frieler, K., Piontek, F., Warszawski, L., and Kabat, P.: Multimodel assessment of water scarcity under climate change, P. Natl. Acad. Sci. USA, 111, 3245-3250, https://doi.org/10.1073/pnas.1222460110, 2014.

Schneider, A., Friedl, M. A., and Potere, D.: A new map of global urban extent from MODIS satellite data, Environ. Res. Lett., 4, 44003, https://doi.org/10.1088/1748-9326/4/4/044003, 2009.

Schyns, J. F., Hoekstra, A. Y., and Booij, M. J.: Review and classification of indicators of green water availability and scarcity, Hydrol. Earth Syst. Sci., 19, 4581-4608, https://doi.org/10.5194/hess-19-4581-2015, 2015.

Sellers, P. J., Dickinson, R. E., Randall, D. A., Betts, A. K., Hall, F. G., Berry, J. A., Collatz, G. J., Denning, A. S., Mooney, H A., Nobre, C. A., Sato, N., Field, C. B., and Henderson-Sellers, A.: Modeling the Exchanges of Energy, Water, and Carbon Be- 
tween Continents and the Atmosphere, Science, 275, 502-509, https://doi.org/10.1126/science.275.5299.502, 1997.

Sheffield, J. and Wood, E. F.: Projected changes in drought occurrence under future global warming from multi-model, multiscenario, IPCC AR4 simulations, Clim. Dynam., 31, 79-105, https://doi.org/10.1007/s00382-007-0340-z, 2008.

Shukla, J. and Mintz, Y.: Influence of Land-Surface Evapotranspiration on the Earth's Climate, Science, 215, 1498-1501, https://doi.org/10.1126/science.215.4539.1498, 1982.

Siebert, S. and Döll, P.: Quantifying blue and green virtual water contents in global crop production as well as potential production losses without irrigation, J. Hydrol., 384, 198-217, 2010.

Siebert, S., Burke, J., Faures, J. M., Frenken, K., Hoogeveen, J., Döll, P., and Portmann, F. T.: Groundwater use for irrigation - a global inventory, Hydrol. Earth Syst. Sci., 14, 1863-1880, https://doi.org/10.5194/hess-14-1863-2010, 2010.

Siebert, S., Kummu, M., Porkka, M., Döll, P., Ramankutty, N., and Scanlon, B. R.: A global data set of the extent of irrigated land from 1900 to 2005, Hydrol. Earth Syst. Sci., 19, 1521-1545, https://doi.org/10.5194/hess-19-1521-2015, 2015.

Stahl, K., Hisdal, H., Hannaford, J., Tallaksen, L. M., van Lanen, H. A. J., Sauquet, E., Demuth, S., Fendekova, M., and Jódar, J.: Streamflow trends in Europe: evidence from a dataset of nearnatural catchments, Hydrol. Earth Syst. Sci., 14, 2367-2382, https://doi.org/10.5194/hess-14-2367-2010, 2010.

Stahl, K., Kohn, I., Blauhut, V., Urquijo, J., De Stefano, L., Acácio, V., Dias, S., Stagge, J. H., Tallaksen, L. M., Kampragou, E., Van Loon, A. F., Barker, L. J., Melsen, L. A., Bifulco, C., Musolino, D., de Carli, A., Massarutto, A., Assimacopoulos, D., and Van Lanen, H. A. J.: Impacts of European drought events: insights from an international database of text-based reports, Nat. Hazards Earth Syst. Sci., 16, 801-819, https://doi.org/10.5194/nhess16-801-2016, 2016.

Steffen, W., Grinevald, J., Crutzen, P., and McNeill, J.: Anthropocene: conceptual and historical perspectives, Philos. T. R. Soc. A, 369, 842-867, https://doi.org/10.1098/rsta.2010.0327, 2011.

Sterling, S. M., Ducharne, A., and Polcher, J.: The impact of global land-cover change on the terrestrial water cycle, Nature Clim. Change, 3, 385-390, https://doi.org/10.1038/nclimate1690, 2013.

Sivapalan, M.: Debates - perspectives on socio-hydrology: changing water systems and the "tyranny of small problems," - sociohydrology, Water Resour. Res., 51, 4795-4805. https://doi.org/10.1002/2015WR017080, 2015.

Sivapalan, M. and Blöschl, G.: Time scale interactions and the coevolution of humans and water, Water Resour. Res., 51, 69887022, https://doi.org/10.1002/2015WR017896, 2015.

Sivapalan, M., Savenije, H. H. G., and Blöschl, G.: Sociohydrology: A new science of people and water, Hydrol. Process., 26, 12701276, https://doi.org/10.1002/hyp.8426, 2012.

Sivapalan, M., Konar, M., Srinivasan, V., Chhatre, A., Wutich, A., Scott, C. A., Wescoat, J. L., and RodriguezIturbe, I.: Socio-hydrology: use-inspired water sustainability science for the anthropocene, Earth's Future, 2, 225-230, https://doi.org/10.1002/2013EF000164, 2014.

Sood, A. and Smakhtin, V.: Global hydrological models: a review, Hydrol. Sci. J., 60, 549-565, https://doi.org/10.1080/02626667.2014.950580, 2015.
Sorooshian, S., AghaKouchak, A., and Li, J.: Influence of irrigation on land hydrological processes over California, J. Geophys. Res.-Atmos., 119, 13137-13152, https://doi.org/10.1002/2014JD022232, 2014.

Strassberg, G., Scanlon, B. R., and Chambers, D.: Evaluation of groundwater storage monitoring with the GRACE satellite: Case study of the High Plains aquifer, central United States, Water Resour. Res., 45, W05410, https://doi.org/10.1029/2008WR006892, 2009.

Takata, K., Emori, S., and Watanabe, T.: Development of the minimal advanced treatments of surface interaction and runoff, Global Planet. Change, 38, 209-222, https://doi.org/10.1016/S0921-8181(03)00030-4, 2003.

Tallaksen, L. M. and Stahl, K.: Spatial and temporal patterns of large-scale droughts in Europe: Model dispersion and performance, Geophys. Res. Lett., 41, 429-434, https://doi.org/10.1002/2013GL058573, 2014.

Tang, Q., Oki, T., Kanae, S., and Hu, H.: The influence of precipitation variability and partial irrigation within grid cells on a hydrological simulation, J. Hydrometeorol., 8, 499-512, https://doi.org/10.1175/JHM589.1, 2007.

Tang, Q. H., Peterson, S., Cuenca, R. H., Hagimoto, Y., and Lettenmaier, D. P.: Satellite-based near-real-time estimation of irrigated crop water consumption, J. Geophys. Res. Atmos., 114, D05114, https://doi.org/10.1029/2008jd010854, 2009.

Tanoue, M., Hirabayashi, Y., and Ikeuchi, H.: Global-scale river flood vulnerability in the last 50 years, Sci. Rep., 6, 36021, https://doi.org/10.1038/srep36021, 2016.

Tapley, B. D., Bettadpur, S., Ries, J. C., Thompson, P. F., and Watkins, M. M.: GRACE Measurements of Mass Variability in the Earth System, Science, 305, 503-505, https://doi.org/10.1126/science.1099192, 2004.

Taylor, R. G., Scanlon, B., Döll, P., Rodell, M., van Beek, R., Wada, Y., Longuevergne, L., Leblanc, M., Famiglietti, J. S., Edmunds, M., Konikow, L., Green, T. R., Chen, J., Taniguchi, M., Bierkens, M. F. P., MacDonald, A., Fan, Y., Maxwell, R. M., Yechieli, Y., Gurdak, J. J., Allen, D. M., Shamsudduha, M., Hiscock, K., Yeh, P. J.-F., Holman, I., and Treidel, H.: Groundwater and climate change, Nature Clim. Change, 3, 322-329, https://doi.org/10.1038/nclimate1744, 2013.

Thornthwaite, C. W. and Mather, J. R.: Instructions and tables for computing potential evapotranspiration and the water balance, Climatology, 10, 183-311, 1957.

Troy, T. J., Konar, M., Srinivasan, V., and Thompson, S.: Moving sociohydrology forward: a synthesis across studies, Hydrol. Earth Syst. Sci., 19, 3667-3679, https://doi.org/10.5194/hess-19-36672015, 2015a.

Troy, T. J., Pavao-Zuckerman, M., and Evans, T. P.: DebatesPerspectives on socio-hydrology: Socio-hydrologic modeling: Tradeoffs, hypothesis testing, and validation, Water Resour. Res., 51, 4806-4814, https://doi.org/10.1002/2015WR017046, $2015 \mathrm{~b}$.

Tuinenburg, O. A., Hutjes, R. W. A., and Kabat, P.: The fate of evaporated water from the Ganges basin, J. Geophys. Res., 117, D01107, https://doi.org/10.1029/2011JD016221, 2012.

van Beek, L. P. H., Wada, Y., and Bierkens, M. F. P.: Global monthly water stress: I. Water balance and water availability, Water Resour. Res., 47, W07517, https://doi.org/10.1029/2010WR009791, 2011. 
van Dijk, A. I. J. M. and Renzullo, L. J.: Water resource monitoring systems and the role of satellite observations, Hydrol. Earth Syst. Sci., 15, 39-55, https://doi.org/10.5194/hess-15-39-2011, 2011.

van Dijk, A. I. J. M., Beck, H. E., Crosbie, R. S., de Jeu, R. A. M., Liu, Y. Y., Podger, G. M., Timbal, B., and Viney, N. R.: The Millennium Drought in southeast Australia (2001-2009): Natural and human causes and implications for water resources, ecosystems, economy, and society, Water Resour. Res., 49, 1040-1057, https://doi.org/10.1002/wrcr.20123, 2013.

van Dijk, A. I. J. M., Renzullo, L. J., Wada, Y., and Tregoning, P.: A global water cycle reanalysis (2003-2012) merging satellite gravimetry and altimetry observations with a hydrological multi-model ensemble, Hydrol. Earth Syst. Sci., 18, 2955-2973, https://doi.org/10.5194/hess-18-2955-2014, 2014.

van Emmerik, T. H. M., Li, Z., Sivapalan, M., Pande, S., Kandasamy, J., Savenije, H. H. G., Chanan, A., and Vigneswaran, S.: Socio-hydrologic modeling to understand and mediate the competition for water between agriculture development and environmental health: Murrumbidgee River basin, Australia, Hydrol. Earth Syst. Sci., 18, 4239-4259, https://doi.org/10.5194/hess-184239-2014, 2014.

van Huijgevoort, M. H. J., Hazenberg, P., van Lanen, H. A. J., Teuling, R., Clark, D., Folwell, S., Gosling, S., Hanasaki, N., Heinke, J., Koirala, S., Stacke, T., Voß, F., Sheffield J., and Uijlenhoet, R.: Global multi-model analysis of hydrological drought in the second part of the 20th century (1963-2000), J. Hydrometeorol., 14, 1535-1552, https://doi.org/10.1175/JHM-D-12-0186.1, 2013.

van Huijgevoort, M. H. J., van Lanen, H. A. J., Teuling, A. J., and Uijlenhoet, R.: Identification of changes in hydrological drought characteristics from a multi-GCM driven ensemble constrained with observed discharge, J. Hydrol., 512, 421-434, doi.org/10.1016/j.jhydrol.2014.02.060, 2014.

van Loon, A. F. and van Lanen, H. A. J.: Making the distinction between water scarcity and drought using an observationmodeling framework, Water Resour. Res., 49, 1483-1502, https://doi.org/10.1002/wrcr.20147, 2013.

van Loon, A. F., Gleeson, T., Clark, J., van Dijk, A. I. J. M., Stahl, K., Hannaford, J., Di Baldassarre, G., Teuling, A. J., Tallaksen, L. M., Uijlenhoet, R., Hannah, D. M., Sheffield, J., Svoboda, M., Verbeiren, B., Wagener, T., Rangecroft, S., Wanders, N., and van Lanen, H. A. J.: Drought in the Anthropocene, Nat. Geosci., 9, 89-91, https://doi.org/10.1038/ngeo2646, 2016.

Veldkamp, T. I. E., Wada, Y., de Moel, H., Kummuc, M., Eisner, S., Aerts, J. C. J. H., and Ward, P. J.: Changing mechanism of global water scarcity events: Impacts of socioeconomic changes and inter-annual hydroclimatic variability, Global Environ. Chang., 32, 18-29, https://doi.org/10.1016/j.gloenvcha.2015.02.011, 2015.

Veldkamp, T. I. E., Wada, Y., Aerts, J. C. J. H., Döll, P., Gosling, S. N., Liu, J., Masaki, Y., Oki, T., Ostberg, S., Pokhrel, Y., Satoh, Y., and Ward, P. J.: Water scarcity hotspots travel downstream due to human interventions in the 20th and 21st century, Nature Commun., 8, 15697, https://doi.org/10.1038/ncomms15697, 2017.

Villarini, G.: Evaluation of the research-version TMPA rainfall estimate at its finest spatial and temporal scales over the Rome metropolitan area, J. Appl. Meteorol. Clim., 49, 2591-2602, https://doi.org/10.1175/2010JAMC2462.1, 2010.

Viglione, A., Di Baldassarre, G., Brandimarte, L., Kuil, L., Carr, G., Salinas, J. L., Scolobig, A., and Blöschl, G.: Insights from socio-hydrology modeling on dealing with flood risk - Roles of collective memory, risk-taking attitude and trust, J. Hydrol., 518, 71-82, https://doi.org/10.1016/j.jhydrol.2014.01.018, 2014.

Voisin, N., Li, H., Ward, D., Huang, M., Wigmosta, M., and Leung, L. R.: On an improved sub-regional water resources management representation for integration into earth system models, Hydrol. Earth Syst. Sci., 17, 3605-3622, https://doi.org/10.5194/hess-173605-2013, 2013.

Vörösmarty, C. J., Moore, B., Grace, A. L., Gildea, M. P., Melillo, J. M., Peterson, B. J., Rastetter, E. B., and Steudler, P. A.: Continental scale models of water balance and fluvial transport: An application to South America, Global Biogeochem. Cy., 3, 241265, https://doi.org/10.1029/GB003i003p00241, 1989.

Vörösmarty, C. J., Federer, C. A., and Schloss, A. L.: Potential evaporation functions compared on US watersheds: Possible implications for global-scale water balance and terrestrial ecosystem modeling, J. Hydrol., 207, 147-169, https://doi.org/10.1016/S0022-1694(98)00109-7, 1998.

Vörösmarty, C. J., Green, P., Salisbury, J., and Lammers, R. B.: Global water resources: Vulnerability from climate change and population growth, Science, 289, 284-288, 2000.

Vörösmarty, C. J., Douglas, E. M., Green, P. A., and Revenga, C.: Geospatial indicators of emerging water stress: an application to Africa, Ambio, 34, 230-236, https://doi.org/10.1579/0044-744734.3.230, 2005.

Vörösmarty, C. J., McIntyre, P., Gessner, M. O., Dudgeon, D., Prusevich, A., Green, P., Glidden, S., Bunn, S. E., Sullivan, C. A., and Liermann, C. R.: Global threats to human water security and river biodiversity, Nature, 467, 555-561, 2010.

Voutchkov, N.: Desalination Engineering: Planning and Design, McGraw-Hill Professional Publishing, New York, ISBN-13: 978-0-07-177716-2, 642 pp., 2012.

Wada, Y., van Beek, L. P. H., van Kempen, C. M., Reckman, J. W. T. M., Vasak, S., and Bierkens, M. F. P.: Global depletion of groundwater resources, Geophys. Res. Lett., 37, L20402, https://doi.org/10.1029/2010GL044571, 2010.

Wada, Y., van Beek, L. P. H., and Bierkens, M. F. P.: Modelling global water stress of the recent past: on the relative importance of trends in water demand and climate variability, Hydrol. Earth Syst. Sci., 15, 3785-3808, https://doi.org/10.5194/hess-15-37852011, 2011a.

Wada, Y., van Beek, L. P. H., Viviroli, D., Dürr, H. H.,Weingartner, R., and Bierkens, M. F. P.: Global monthly water stress: II. Water demand and severity of water, Water Resour. Res., 47, W07518, https://doi.org/10.1029/2010WR009792, 2011b.

Wada, Y., van Beek, L. P. H., Wanders, N., and Bierkens, M. F. P.: Human water consumption intensifies hydrological drought worldwide, Environ. Res. Lett., 8, 034036, https://doi.org/10.1088/1748-9326/8/3/034036, 2013a.

Wada, Y., Wisser, D., Eisner, S., Flörke, M., Gerten, D., Haddeland, I., Hanasaki, N., Masaki, Y., Portmann, F. T., Stacke, T., Tessler, Z., and Schewe, J.: Multi-model projections and uncertainties of irrigation water demand under climate change, Geophys. Res Lett., 40, 4626-4632, https://doi.org/10.1002/grl.50686, $2013 \mathrm{~b}$.

Wada, Y., Wisser, D., and Bierkens, M. F. P.: Global modeling of withdrawal, allocation and consumptive use of surface water and groundwater resources, Earth Syst. Dynam., 5, 15-40, https://doi.org/10.5194/esd-5-15-2014, 2014. 
Wada, Y., Lo, M.-H., Yeh, P. J.-F., Reager, J. T., Famiglietti, J. S., $\mathrm{Wu}, \mathrm{R} .-\mathrm{J}$. , and Tseng, Y.-H.: Fate of water pumped from underground causing sea level rise, Nature Clim. Change, 6, 777-780, https://doi.org/10.1038/nclimate3001, 2016a.

Wada, Y., de Graaf, I. E. M., and van Beek, L. P. H.: High-resolution modeling of human and climate impacts on global water resources, J. Adv. Model Earth Sy., 8, 735-763, https://doi.org/10.1002/2015MS000618, 2016b.

Wada, Y., Flörke, M., Hanasaki, N., Eisner, S., Fischer, G., Tramberend, S., Satoh, Y., van Vliet, M. T. H., Yillia, P., Ringler, C., Burek, P., and Wiberg, D.: Modeling global water use for the 21st century: the Water Futures and Solutions (WFaS) initiative and its approaches, Geosci. Model Dev., 9, 175-222, https://doi.org/10.5194/gmd-9-175-2016, 2016c.

Wanders, N. and Wada, Y.: Human and climate impacts on the 21st century hydrological drought, J. Hydrol., 526, 208-220, https://doi.org/10.1016/j.jhydrol.2014.10.047, 2015a.

Wanders, N. and Wada, Y.: Decadal predictability of river discharge with climate oscillations over the 20th and early 21 st century, Geophys. Res. Lett., 42, 10689-10695, https://doi.org/10.1002/2015GL066929, 2015 b.

Wanders, N. and Van Lanen, H. A. J.: Future discharge drought across climate regions around the world modelled with a synthetic hydrological modelling approach forced by three general circulation models, Nat. Hazards Earth Syst. Sci., 15, 487-504, https://doi.org/10.5194/nhess-15-487-2015, 2015.

Wanders, N., Wada, Y., and Van Lanen, H. A. J.: Global hydrological droughts in the 21 st century under a changing hydrological regime, Earth Syst. Dynam., 6, 1-15, https://doi.org/10.5194/esd-6-1-2015, 2015.

Wanders, N., van Huijgevoort, M., van Lanen, H., and Wada, Y.: Natural and human-influenced hydrological simulations for California, https://doi.org/hdl:10411/GP5PKK, DataverseNL Dataverse, V1, 2017.

Warburton, M. L., Schulze, R. E., and Jewitt, G. P. W.: Hydrological impacts of land use change in three diverse South African catchments, J. Hydrol., 414-415, 118-135, https://doi.org/10.1016/j.jhydrol.2011.10.028, 2012.

Wei, J., Dirmeyer, P. A., Wisser, D., Bosilovich, M. J., and Mocko, D. M.: Where does the irrigation water go? An estimate of the contribution of irrigation to precipitation using MERRA, J. Hydrometeor., 14, 275-289, https://doi.org/10.1175/JHM-D-12$079.1,2013$.

Wheater, H. S. and Gober, P.: Water security and the science agenda, Water Resour. Res., 51, 5406-5424, https://doi.org/10.1002/2015WR016892, 2015.

Wilhite, D. A., Svoboda, M. D., and Hayes, M. J.: Understanding the complex impacts of drought: A key to enhancing drought mitigation and preparedness, Water Resour. Manage., 21, 763-774, https://doi.org/10.1007/s11269-006-9076-5, 2007.

Widén-Nilsson, E., Halldin, S., and Xu, C.: Global waterbalance modeling with WASMOD-M: parameter estimation and regionalisation, J. Hydrol., 340, 105-118, https://doi.org/10.1016/j.jhydrol.2007.04.002, 2007.

Winsemius, H. C., Schaefli, B., Montanari, A., and Savenije, H. H. G.: On the calibration of hydrological models in ungauged basins: A framework for integrating hard and soft hydrological information, Water Resour. Res., 45, W12422, https://doi.org/10.1029/2009WR007706, 2009.
Winsemius, H. C., Van Beek, L. P. H., Jongman, B., Ward, P. J., and Bouwman, A.: A framework for global river flood risk assessments, Hydrol. Earth Syst. Sci., 17, 1871-1892, https://doi.org/10.5194/hess-17-1871-2013, 2013.

Wisser, D., Frolking, S., Douglas, E. M., Fekete, B. M., Vörösmarty, C. J., and Schumann, A. H.: Global irrigation water demand: Variability and uncertainties arising from agricultural and climate data sets, Geophys. Res. Lett., 35, L24408, https://doi.org/10.1029/2008GL035296, 2008.

Wisser, D., Fekete, B. M., Vörösmarty, C. J., and Schumann, A. H.: Reconstructing 20th century global hydrography: a contribution to the Global Terrestrial Network- Hydrology (GTN-H), Hydrol. Earth Syst. Sci., 14, 1-24, https://doi.org/10.5194/hess14-1-2010, 2010.

Wohlfart, C., Liu, G., Huang, C., and Kuenzer, C.: A River Basin over the course of time: Multi-temporal analyses of land surface dynamics in the Yellow River Basin (China) based on medium resolution remote sensing data, Remote Sens., 8, 186, https://doi.org/10.3390/rs8030186, 2016.

Wood, E. F., Lettenmaier, D. P., and Zartarian, V. G.: A land-surface hydrology parameterization with subgrid variability for general circulation models, J. Geophys. Res. Atmos., 97, 2717-2728, https://doi.org/10.1029/91JD01786, 1992.

Wood, E. F., Roundy, J. K., Troy, T. J., van Beek, L. P. H., Bierkens, M. F. P., Blyth, E., de Roo, A., Döll, P., Ek, M., Famiglietti, J., Gochis, D., van de Giesen, N., Houser, P., Jaffé, P. R., Kollet, S., Lehner, B., Lettenmaier, D. P., Peters-Lidard, C., Sivapalan, M., Sheffield, J., Wade, A., and Whitehead, P.: Hyperresolution global land surface modeling: Meeting a grand challenge for monitoring Earth's terrestrial water, Water Resour. Res., 47, W05301, https://doi.org/10.1029/2010WR010090, 2011.

World Water Assessment Programme (WWAP): Water for people: Water for life, The United Nations World Water Development Report, UNESCO, Paris, France, 2003.

World Water Assessment Programme (WWAP): Water and Jobs. Facts and Figures, The United Nations World Water Development Report, UNESCO Perugia, 2016.

Yang, G., Bowling, L. C., Cherkauer, K. A., and Pijanowski, B. C.: The impact of urban development on hydrologic regime from catchment to basin scales, Landsc. Urban Plan., 103, 237-247, https://doi.org/10.1016/j.landurbplan.2011.08.003, 2011.

Yang, L., Huang, C., Homer, C. G., Wylie, B. K., and Coan, M. J.: An approach for mapping large-area impervious surfaces: Synergistic use of Landsat-7 ETM+ and high spatial resolution imagery, Can. J. Remote Sens., 29, 230-240, https://doi.org/10.5589/m02-098, 2003.

Yates, D. N.: Approaches to continental scale runoff for integrated assessment models, J. Hydrol., 291, 289-310, https://doi.org/10.1016/S0022-1694(97)00044-9, 1997.

Yin, Y., Tang, Q., Liu, X., and Zhang, X.: Water scarcity under various socio-economic pathways and its potential effects on food production in the Yellow River basin, Hydrol. Earth Syst. Sci., 21, 791-804, https://doi.org/10.5194/hess-21-791-2017, 2017.

Zeng, Z., Liu, J., and Savenije, H. H. G.: A simple approach to assess water scarcity integrating water quantity and quality, Ecol. Indic., 34, 441-449, https://doi.org/10.1016/j.ecolind.2013.06.012, 2013.

Zhang, K., Kimball, J. S., Nemani, R. R., and Running, S. W.: A continuous satellite-derived global record of land surface 
evapotranspiration from 1983 to 2006, Water Resour. Res., 46, W09522, https://doi.org/10.1029/2009WR008800, 2010.

Zhao, X., Liu, J., Liu, Q., Tillotson, M. R., Guan, D., and Hubacek, K.: Physical and virtual water transfers for regional water stress alleviation in China, P. Natl. Acad. Sci. USA., 112, 1031-1035, https://doi.org/10.1073/pnas.1404130112, 2015.
Zhou, T., Nijssen, B., Huffman, G. J., and Lettenmaier, D. P.: Evaluation of Real-Time Satellite Precipitation Data for Global Drought Monitoring, J. Hydrometeorol., 15, 1651-1660, https://doi.org/10.1175/JHM-D-13-0128.1, 2014. 